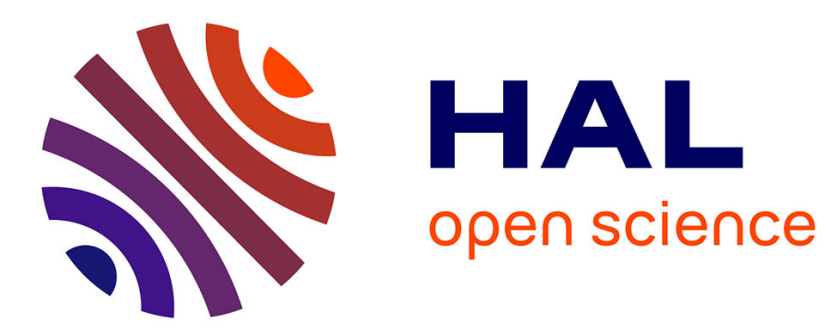

\title{
Phonemic and tonal analysis of Yongning $\mathrm{Na}$
}

Alexis Michaud

\section{To cite this version:}

Alexis Michaud. Phonemic and tonal analysis of Yongning Na. Cahiers de linguistique - Asie Orientale, 2008, 37 (2), pp.159-196. halshs-00358610

\section{HAL Id: halshs-00358610 \\ https://shs.hal.science/halshs-00358610}

Submitted on 3 Feb 2009

HAL is a multi-disciplinary open access archive for the deposit and dissemination of scientific research documents, whether they are published or not. The documents may come from teaching and research institutions in France or abroad, or from public or private research centers.
L'archive ouverte pluridisciplinaire HAL, est destinée au dépôt et à la diffusion de documents scientifiques de niveau recherche, publiés ou non, émanant des établissements d'enseignement et de recherche français ou étrangers, des laboratoires publics ou privés. 


\title{
Phonemic and tonal analysis of Yongning $\mathrm{Na}^{*}$
}

\begin{abstract}
Alexis MICHAUD
The Na language spoken in the village of Yongning, close to the border between Yunnan and Sichuan, has been classified as an Eastern Naxi dialect in the pioneering survey conducted by Chinese linguists. It is also referred to as 'Mosuo'. The phonemic and tonal analysis presented here on the basis of first-hand fieldwork aims to serve as a basis for linguistic documentation and research, from the accurate transcription of recorded materials to fine-grained synchronic and diachronic investigations. The ultimate aim is an in-depth understanding of $\mathrm{Na}$, Naxi and other closely related language varieties, including an account of their historical relationships and their links with other Tibeto-Burman languages.
\end{abstract}

Keywords : Na; Eastern Naxi; Mosuo; phonemes; phonetics/phonology.

Le parler na (parfois appelé 'mosuo') du village de Yongning, près de la frontière entre le Yunnan et le Sichuan, a été classé dans les travaux pionniers de linguistes chinois comme un dialecte oriental du naxi. L'analyse phonémique et tonale présentée ici, sur la base d'enquêtes de première main, a pour finalité de servir de référence pour la documentation et la recherche, de la transcription des données jusqu'aux études les plus ciblées, tant synchroniques que diachroniques. L'objectif à long terme est de parvenir à une connaissance approfondie des dialectes na et naxi, de leur histoire, et des relations qu'ils entretiennent entre eux et avec les autres langues tibéto-birmanes.

Mots-clefs : na ; naxi oriental ; mosuo ; phonèmes ; phonétique/phonologie.

\footnotetext{
* Many thanks to the three reviewers of this article, and to the Editors; to Latami Dashi (拉他咪 - 达石) for help during fieldwork; to the language consultants for their hospitality and their patience; and to E. Chirkova, G. Jacques, L. Lidz, M. Mazaudon, B. Michailovsky, A. Rialland and L. Wetzels for useful discussions. None of them is responsible for any of the remaining shortcomings. The third stay in Yongning (2008) was funded as part of a project headed by E. Chirkova: ANR-PASQi.
}

Cahiers de Linguistique - Asie Orientale 37(2): pp-pp (2008)

(C) CRLAO-EHESS 54, Bd Raspail 75006 Paris

0153-3320/2008/037- 
Michaud A. / Cahiers de Linguistique - Asie Orientale 37(2008) pp-pp

\section{INTRODUCTION}

\subsection{Research aims and outline of the article}

The Tibeto-Burman language described in this article, Yǒngníng Nà 永宁纳语, is closely related to Nàxī 纳西语; however, the exact correspondences still need to be worked out, and there also remains much comparative work to be done in order to clarify the position of the $\mathrm{Na} / \mathrm{Naxi}$ languages within Tibeto-Burman. Naxi was considered a member of the Yi group (a.k.a. Ngwi, Lo-lo) until Bradley 1975 showed that it does not share the common innovations that characterise this group. Naxi and $\mathrm{Na}$ have strong resemblances with neighbouring languages currently classified as Qiangic, such as Shǐxīng 史兴 and Nàmùyī 纳木依 (see, e.g., Yáng Fúquán 杨福泉 2006, Lāmă Zīwò 拉玛兹偓 1994). Detailed comparisons will allow for a reassessment of current classifications, and for progress in reconstruction.

For this and other research purposes, in-depth descriptions are required. A phonemic and tonal analysis based on a distributional inventory constitutes a necessary basis for all aspects of linguistic documentation and research, from the accurate transcription of recorded materials to fine-grained synchronic and diachronic investigations. The theoretical backdrop to the present research is classical functional phonology (Martinet 1956:15, 3447). The synchronic inventory is supplemented by comparative and diachronic observations - an approach advocated by Martinet under the name of dynamic synchrony (Martinet 1990). Some concepts used in the tonal analysis are drawn from 'autosegmental' models, which were originally developed for Subsaharan tone systems but have been convincingly applied to certain Tibeto-Burman languages (see, in particular, Hyman and VanBik 2002). 
Phonemic and tonal analysis of Yongning Na / CLAO 37(2008) pp-pp

The present analyses are based on three field trips, in 2006, 2007 and 2008 (total time in Yongning: three months). ${ }^{1}$

This article consists of a brief presentation of the language (§1.2.) and of its phonemic inventory (§1.3.), followed by observations about consonants (section 2) and vowels (section 3). Section 4 deals with the tone system. ${ }^{2}$

\subsection{Background on the Yǒngníng Na language}

The Tibeto-Burman language under study here, Yongning $\mathrm{Na}$, is spoken in the plain of Yǒngníng (永宁; Tibetan thar lam), located at the border between Yunnan and Sichuan, at a latitude of $27^{\circ} 50^{\prime} \mathrm{N}$ and a latitude of $100^{\circ} 41^{\prime} \mathrm{E}$. The history of Yongning as presented by the Naxi scholars Guō Dàliè 郭大烈 and Hé Zhìwŭ 和 志武 can be summarised as follows: in 794 AD, the Nánzhāo kingdom (南诏) conquered the Na/Naxi area, including Yongning; after the fall of Nanzhao, the kingdom of Dàlǐ (大理国, 937-1253) exercised control over Yongning, whereas the area of present-day Lijiāng (丽江) was ruled by an indigenous lord allied with Dali. During the Yuan and Ming dynasties, incessant wars took place between the feudal lords (tǔsī 土司) of Yongning, Lijiang and

\footnotetext{
${ }^{1}$ The location chosen for fieldwork is a hamlet located in the Yongning plain proper. Its name in $\mathrm{Na}$ is $/{ }^{\mathrm{MH}} \mathrm{br} . \mathrm{ss}^{\mathrm{h}} \mathrm{u} . \mathrm{gy} /$, and its administrative coordinates are: Yúnnán province, Lijiāng municipality, Nínglàng Yí autonomous county, Yǒngníng district, Píngjìng village (云南省丽江市宁蒗彝族自治县永宁乡平静 村). It is close to the monastery of Yongning, called dgra med dgon pa in Tibetan, a name rendered in Chinese as Zhāměisì 扎美寺.

${ }^{2}$ The main language consultant is a woman who was born in 1950 and has lived in Yongning all her life. The data recorded include a word list of some 2,000 items, elicited sentences, and narratives (folk tales and stories about Yongning). The data were checked with one male speaker of the same generation. One female and one male speaker one generation younger - in their mid-thirties - also participated in the investigation.
} 
Michaud A. / Cahiers de Linguistique - Asie Orientale 37(2008) pp-pp

Yányuán (盐源). In 1545, Yongning united with the neighbouring areas of the five 所 suǒ (zuǒsuǒ 左所, yòusuǒ 右所, qiánsuǒ 前所, hòusuǒ 后所, zhōngsuǒ 中所). The Yangtse river constituted the border between the territories of Yongning and Lijiang (Guo Dalie and He Zhiwu 1994 [2nd ed. 1999]). Part of the relevant Chinese historical sources on $\mathrm{Na} / \mathrm{Naxi}$ history are summarised by Chavannes 1912 (reprinted in Bacot 1913). Chinese-language articles published since 1960 about the $\mathrm{Na}$ of the Yongning area have recently been collected in two volumes (Lātāmī Dáshí 拉他咪·达石 2006). An outline of the history of this part of Yunnan is presented by Gros 1996.

From a linguistic point of view, Yongning $\mathrm{Na}^{3}$ was investigated in 1979 by the linguists Hé Jírén 和即仁 and Jiāng Zhúyí 姜竹仪, who classified it among the Eastern Naxi dialects (He Jiren and Jiang Zhuyi 1985:4, 104-116). The division between Western and Eastern dialect areas proposed by He and Jiang by and large corresponds to the historical divide between the areas ruled by the lords of Lijiang (Western dialects) and those further to the

\footnotetext{
${ }^{3}$ The term "Yongning Na", used by Lidz 2006, appears to be a more adequate designation for the language than "Yongning Naxi" insofar as the autonym used by the speakers is simply "Na" $\left(/^{\mathrm{LM}} \mathrm{na} /\right)$, unlike the autonym used in and around the city of Lijiang: / ${ }^{\mathrm{L}} \mathrm{na}{ }^{\mathrm{M}} \mathrm{hi} /$, where $/{ }^{\mathrm{M}} \mathrm{hi} / \mathrm{means}$ 'human being'. Other designations of this language include "Eastern dialect of Naxi, Yongning variety", and "Yongning variety of the Mosuo language". "Mosuo" (摩梭 mósuō), which has several alternative transcriptions in Chinese characters (摩娑, 摩沙, 麼些, 磨些, 未些...), is a name formerly used in the Chinese records. Chavannes 1912:132 cites Chinese chronicles as indicating that the Mo-so tribe was formed during the Nanzhao period out of two distinct elements, the Mo and the So. This name was officially replaced after 1949 by "Naxi" (纳西 nàxī). Thus, the dictionary of pictograms originally published by Li Lincan 李霖灿, Zhang Kun 张琨 and He Cai 和才 as Dictionary of Mo-So Hieroglyphics [Hong Kong, 1953], 麼些象形文字字典, was reprinted in 2001 on the mainland under the title Dictionary of Naxi pictograms, 纳 西族象形文字字典; all occurrences of 麼些 within the book were replaced by 纳 西. Today, the term “Mosuo" has been revived to refer to the Na of the Yongning area: since the 1990s, the "Mosuo" are recognised (at the provincial level) as a separate subgroup within the Naxi nationality.
} 
Phonemic and tonal analysis of Yongning Na / CLAO 37(2008) pp-pp

East/North-East (Eastern dialects: Yongning, Yanyuan, Mùlǐ 木里, Yánbiān 盐边). Their book includes a word list of the Yongning dialect, as well as some observations on phonology, syntax, and dialectal diversity (ibid., pp. 107-116; see also Jiang Zhuyi 1993). A brief outline of the language was recently published by Yáng Zhènhóng 杨振洪, who took up the structure of He and Jiang's description of Western Naxi (Yang Zhenhong 2006). The variety of Yongning Na spoken in the village of Luòshui 落水 is currently investigated by Liberty Lidz ( $\operatorname{Lidz} 2006$, 2007, to appear). The phonemic analysis presented here differs somewhat from those proposed by Yang Zhenhong and Liberty Lidz, partly due to dialectal differences. A detailed comparison of the three descriptions must be deferred until a cross-dialect comparison can be carried out.

\subsection{Table of the phonemes of Yongning $\mathrm{Na}$}

Syllabic structure in Yongning $\mathrm{Na}$ is simply $(\mathrm{C})(\mathrm{G}) \mathrm{V}$, where $\mathrm{C}$ is a consonant, $\mathrm{G}$ a glide - with a severely restricted distribution and $\mathrm{V}$ a syllable nucleus; the brackets indicate that $\mathrm{C}$ and $\mathrm{G}$ are optional. It therefore appears simplest to present the inventory in Table 1 in terms of initials, corresponding to consonants, and rhymes, corresponding to $(\mathrm{G}) \mathrm{V}$.

Table 1. An inventory of the phonemes of Yongning Na. Initials (top) and rhymes (bottom).

\begin{tabular}{|l|l|l|l|l|l|l|}
\hline & bilabial & dental & retroflex & velar & uvular & glottal \\
\hline plosive & $\mathrm{p}^{\mathrm{h}} \mathrm{p} \mathrm{b}$ & $\mathrm{t}^{\mathrm{h}} \mathrm{t} \mathrm{d}$ & $\mathrm{t}^{\mathrm{h}} \mathrm{td}$ & $\mathrm{k}^{\mathrm{h}} \mathrm{kg}$ & $\mathrm{q}^{\mathrm{h}} \mathrm{q}$ & \\
\hline affricate & & $\begin{array}{l}\mathrm{ts}^{\mathrm{h}} \mathrm{ts} \mathrm{dz} \\
\mathrm{tc}\end{array}$ & $\mathrm{ts}^{\mathrm{h}} \mathrm{ts} \mathrm{dz}$ & & & \\
\hline nasal & $\mathrm{m}$ & $\mathrm{n}$ & $\mathrm{\eta}$ & $\mathrm{g}$ & & \\
\hline fricative & & $\mathrm{s} \mathrm{z}$ & $\mathrm{s} \mathrm{z}$ & & G & $\mathrm{h}$ \\
& & $6 \mathrm{z}$ & & & & \\
\hline lateral & & $\mathrm{tl}$ & & & & \\
\hline approximant & & & $\mathrm{l}$ & & & \\
\hline
\end{tabular}


Michaud A. / Cahiers de Linguistique - Asie Orientale 37(2008) pp-pp

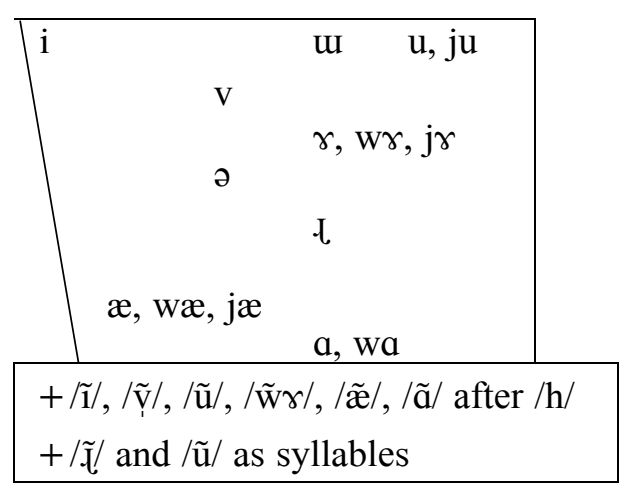

Consonants will be discussed in section 2, and vowels in section 3 .

\section{OBSERVATIONS ABOUT THE CONSONANTS OF YONGNING NA}

2.1. The palatalisation of velars and its consequences

Yongning $\mathrm{Na}$ has undergone a thorough palatalisation of velars in front of $/ \mathrm{i} /$ and $/ \mathrm{j} /$. This is a difference with the Western Naxi dialects, where palatalisation is less advanced (Michailovsky and Michaud 2006). The empty slots in the phonemic system created by this evolution have been filled by syllables whose vowel underwent fronting, as shown in Table 2. 
Phonemic and tonal analysis of Yongning Na / CLAO 37(2008) pp-pp

Table 2. Some Yongning Na cognates of velar-initial syllables of Western Naxi. (In all tables, the Chinese terms are the ones used in elicitation, and the English glosses are translations from the Chinese. $)^{4}$

\begin{tabular}{|c|c|c|}
\hline & Yongning $\mathrm{Na}$ & Western Nax \\
\hline 1. 'water, shuǐ 水' & $/{ }^{\mathrm{L}} \mathrm{dzi} /$ & $/{ }^{\mathrm{L}} \mathrm{gi} /$ \\
\hline $\begin{array}{l}\text { 2. 'to fall (rain), 下 (雨, 雪) } \\
\text { xià (yǔ, xuě)' }\end{array}$ & $/ \mathrm{gi} /\left(\right.$ toneless $\left.^{5}\right)$ & $/{ }^{\mathrm{M}} \mathrm{gu} /$ \\
\hline 3. 'bear (animal), 熊 xióng’ & / ${ }^{\# \mathrm{H}}$ gi.na.mi/ & $/{ }^{\mathrm{L}} \mathrm{gy} /$ \\
\hline 4. ' 'granary, 粮仓 liángcāng' & I $\mathrm{gi} /$ & / ${ }^{\mathrm{nggu} /}$ \\
\hline 5. 'little brother, 弟弟 dìdi' & / ${ }^{\# \mathrm{H}}$ gi.zu/ & $/{ }^{\mathrm{M}} \mathrm{gu}{ }^{\mathrm{M}} \mathrm{zu} /$ \\
\hline 6. 'half, (一) 半 (yí) bàn’ & $/{ }^{\mathrm{H}} \mathrm{gi} /$ & $/{ }^{\mathrm{M}} \mathrm{ggu} /$ \\
\hline 7. existential/' to have, 有 yǒu' & $/{ }^{\mathrm{M}} \mathrm{d} z \mathrm{u} /$ & $/{ }^{\mathrm{M}} \mathrm{gy} /$ \\
\hline
\end{tabular}

Clearly, the conservative form of the word for 'water' is /gi/, whereas /dzi/ is the result of palatalisation. The velar stop + high front vowel syllables of Western Naxi stand in a regular relation of correspondence with alveolo-palatal initial+high front vowel syllables in Yongning Na.

As for the present-day /gi/ syllables of Yongning $\mathrm{Na}$ (exemplified on the $2^{\text {nd }}$ to $6^{\text {th }}$ lines of Table 2), the correspondences are less straightforward. It appears reasonable to hypothesise that these syllables used to have a back vowel (reflected as a back vowel, $/ \mathrm{u} /, / \mathrm{u} /$ or $/ \mathrm{v} /$, in Western dialects) which later became

\footnotetext{
${ }^{4}$ Tone is indicated in superscript to the left of the syllable in Western Naxi, where tone is syllabic, and to the left of the entire word in Yongning Na. The dot (.) in Yongning $\mathrm{Na}$ data represents syllable boundaries. About the tonal system, see section 4, where explanations are provided about how tones unfold over a polysyllabic word.

${ }^{5}$ No tone is indicated for this verb because, unlike other verbs (section 4.1), its tone is determined by that of its subject: $/^{\# \mathrm{H}} \mathrm{bi} /$ 'snow' $>[\mathrm{bi}-\mathrm{gi}-1]$ 'it snows', ${ }^{\mathrm{LM}} \mathrm{hi} /$ 'rain'>[hi」gi $\lambda]$ 'it rains'. This verb thus appears to have become grammaticalised; 'to rain', 'to snow' behave as units, not as subject+verb combinations.
} 
Michaud A. / Cahiers de Linguistique - Asie Orientale 37(2008) pp-pp

fronted, and that these syllables came to occupy the slot left empty by the palatalisation of $* / \mathrm{gi} /$. The same holds for the other syllables made up of a velar stop and a high front vowel, e.g. Yongning $\mathrm{Na}$ $/{ }^{\# \mathrm{H}} \mathrm{k}^{\mathrm{h}} \mathrm{i}$ / 'door' corresponds to Western Naxi $/{ }^{\mathrm{M}} \mathrm{k}^{\mathrm{h}} \mathrm{u} /$. It is a general observation that the high back vowels of Western Naxi have two reflexes in Yongning $\mathrm{Na}$, one being a high back vowel and the other a high front vowel, as shown in Table 3.

Table 3. Some examples of the two reflexes found in Yongning $\mathrm{Na}$ for Western Naxi high back vowels.

\begin{tabular}{|l|l|l|}
\hline & Yongning Na & Western Naxi \\
\hline 'old, 老 lăo' & $/{ }^{\mathrm{L}} \mathrm{mu} /$ & $/{ }^{\mathrm{H}} \mathrm{mu} /$ \\
\hline 'body, 身体 shēntǐ' & $/{ }^{\mathrm{L}} \mathrm{gv} \cdot \mathrm{mi} /$ & $/{ }^{\mathrm{M}} \mathrm{gu}{ }^{\mathrm{M}} \mathrm{mu} /$ \\
\hline 'skin, 皮, 皮肤 pí, pífū' & $/{ }^{\mathrm{LM}} \mathrm{u} /$ & $/{ }^{\mathrm{M}} \mathrm{u} /$ \\
\hline 'cow, 牛(黄牛) niú (huángniú)' & $/{ }^{\mathrm{H}} \mathrm{i} /$ & $/{ }^{\mathrm{M}} \mathrm{u} /$ \\
\hline
\end{tabular}

There is thus a twofold correspondence, e.g. Western Naxi /u/ Yongning $\mathrm{Na} / \mathrm{w} /$, Western Naxi / $\mathrm{u} /$ - Yongning $\mathrm{Na} / \mathrm{i} /$. The conditioning of this change has not been elucidated yet. There exist some syllables that have a velar initial+back vowel both in Western Naxi and in Yongning Na, e.g. '(to be) sick': Western Naxi /L ${ }^{\mathrm{L} g u / \text {, }}$ Yongning $\mathrm{Na} / \mathrm{L}$ gu/.

The case of 'to have', the last example in Table 2, is slightly more complex. The initial underwent palatalisation, from $/ \mathrm{g} /$ to [dz]. An intermediate stage may have been [f]: in Western Naxi, /gi/ is currently realised as [ji]. This implies that the rhyme must have had a palatal component. In the present-day state of the language, the syllable can be analysed phonemically either as $/ \mathrm{d} z /+/ \mathrm{ju} /$ or as $/ \mathrm{d} z /+/ \mathrm{u} /$. It is plausible that the rhyme at an earlier stage was $/ \mathrm{ju} /$; from a synchronic point of view, however, there does not appear to remain any palatal component in the rhyme that could be distinguished from the palatal component of the initial, so that a notation as $/ \mathrm{d} \mathrm{z}_{\mathrm{f}} /+\mathrm{ju} /$ appears unnecessarily redundant. The notation 
chosen here consists of $/ \mathrm{d} z /+/ \mathrm{u} /$, reflecting the intuition that the palatal feature of the rhyme has been entirely transferred onto the initial.

Phonetically, in Western Naxi, velar initials do show a clear tendency towards palatalisation before high front vowels, but they are less fronted than the alveolo-palatals of Yongning Na. The syllables $/ \mathrm{k}^{\mathrm{h}} \mathrm{i} /$, /ki/, /gi/, /ngi/ of Western Naxi can be approximated phonetically as [c ${ }^{\mathrm{h}} \mathrm{i}$, [ci], [ji], [nji] (Michailovsky et al. 2006:14), i.e. with palatal articulation, whereas $/ \mathrm{t}^{\mathrm{h}} \mathrm{i} /, / \mathrm{t} \mathrm{c} \mathrm{i} /, / \mathrm{d} z \mathrm{i} /$ in Yongning $\mathrm{Na}$ are articulated towards the front of the alveolo-palatal region. The phonemic contrast between velars, as in /gi/, and alveolopalatals, as in $/ \mathrm{d} z \mathrm{i} /$, probably contributes to the further fronting of

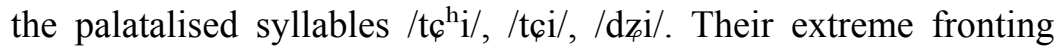
brings them into the phonetic vicinity of the syllables $/ \mathrm{ts}^{\mathrm{h}} \mathrm{w} / \mathrm{h} / \mathrm{tsw} /$, /dzu/. The rhymes of both sets can be described as the voiced continuation of the initial: for instance, /tsu/ is realised as [tsz] (notation in the Chinese tradition: /tss/), and /tci/ could be transcribed in international phonetic notation as [tciz] rather than [tci], since a degree of friction is found throughout the syllable. ${ }^{6}$

The above facts explain the distributional restriction of the alveolo-palatals to syllables with a high, front vowel or an initial palatal glide. The alveolo-palatal fricatives $/ 6 /$ and $/ z /$, too, are exclusively found in combination with /i/. Examples include

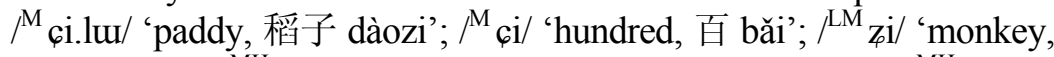
猴子 hóuzi'; $/{ }^{\mathrm{MH}} \mathrm{zi} /$ 'family, 家 jiā' [tone to be verified]; $/{ }^{\mathrm{MH}} \mathrm{zi} /$ ' to sleep, 睡觉 shuijiào'; and /M $z \mathrm{i} /$ 'to flow (river, water), 流 liú'.

2.2. Uvular stops $/ \mathrm{q} /$ and $/ \mathrm{q}^{\mathrm{h}} /$, and uvular fricative $/ \mathrm{s} /$

When they are combined with the rhymes /æ/, /a/, and /wa/, velar stops $/ \mathrm{k} /$ and $/ \mathrm{k}^{\mathrm{h}} /$ are realised somewhat further back than they

\footnotetext{
${ }^{6}$ The diacritic indicating syllabic status is placed over the [i்], not underneath it, for the sake of clarity.
} 
Michaud A. / Cahiers de Linguistique - Asie Orientale 37(2008) pp-pp

are before other rhymes, and with some slight affrication. This is analysed as allophonic variation of the velar stops. However, these stops contrast with another set in front of $/ \mathrm{v} /$, as shown in Table 4. The latter set is articulated further back, and with some affrication. I follow Lidz 2006 in analysing these sounds as uvular $/ \mathrm{q} /$ and $/ \mathrm{q} /$.

Table 4. Some examples illustrating the contrasts between $/ \mathrm{kv} /, / \mathrm{qv} /, / \mathrm{k}^{\mathrm{h}} \mathrm{v} /$ and $/ \mathrm{q}^{\mathrm{h}} \mathrm{y} /$ in Yongning $\mathrm{Na}$

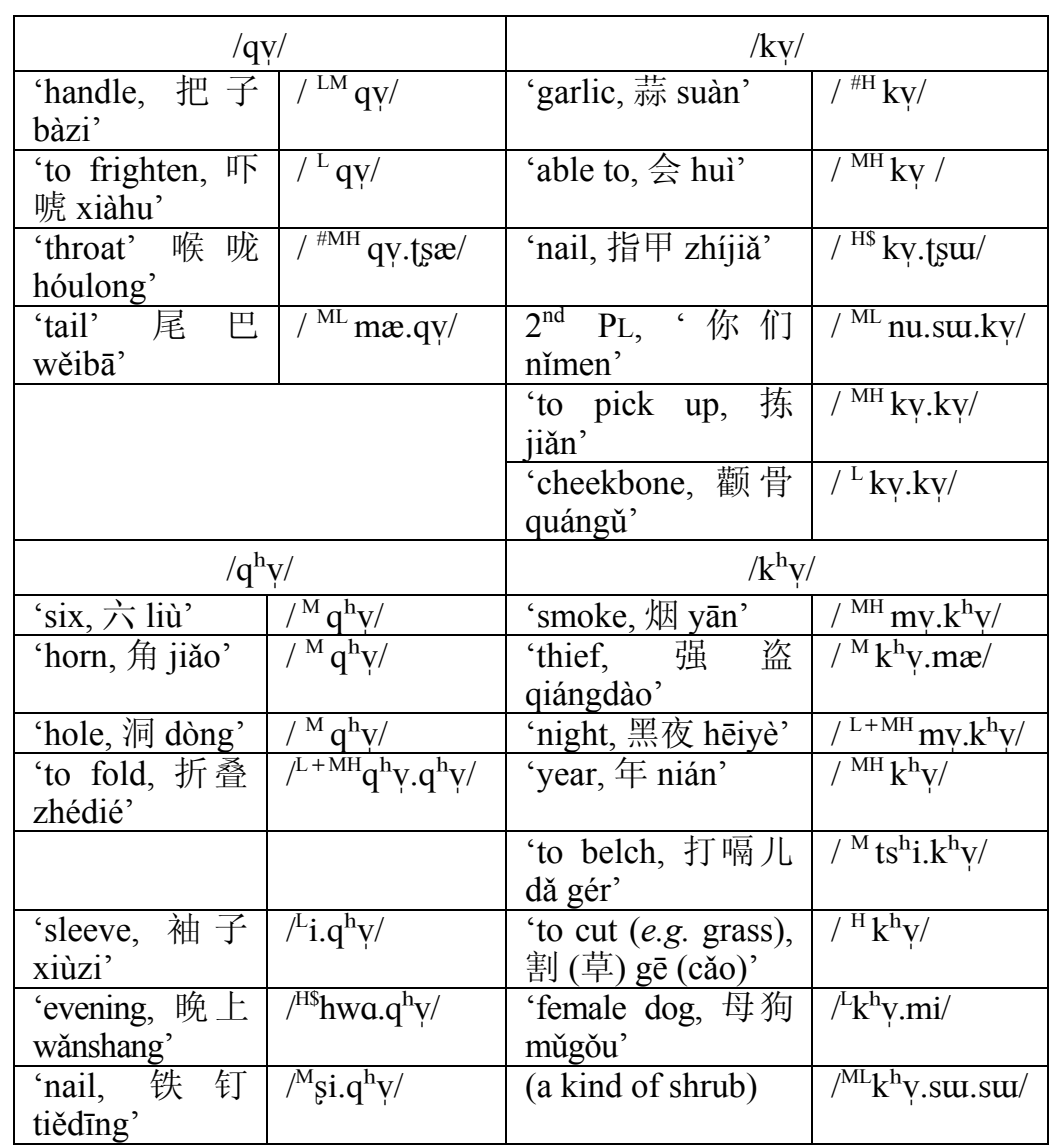


Another option would consist in transcribing affricated velar stops, $/ \mathrm{kx} /\left(\right.$ instead of $/ \mathrm{q} /$ ) and $/ \mathrm{kx}^{\mathrm{h}} /\left(\right.$ instead of $/ \mathrm{q}^{\mathrm{h}} /$ ). The contrast between stops and affricates has a high functional load in Yongning $\mathrm{Na}$, so that the hypothesis of an attraction of $/ \mathrm{q} /$ and $/ \mathrm{q}^{\mathrm{h}} /$ towards the series of affricated consonant phonemes is not altogether implausible. It is not uncommon for a phonetic system to allow for several phonemic interpretations (Chao Yuen-ren 1934). The respective perceptual roles played by the place of articulation and by the degree of affrication have not been evaluated experimentally. However, the interpretation of these consonants as stop uvulars makes sense within the areal context, where uvulars are relatively widespread. From the point of view of the phonemic system, the fricative /ь/ could originate in an earlier voiced uvular stop $/ \mathrm{G} /{ }^{7}-$ again for simple phonetic reasons: maintaining voicing during oral stops is difficult, due to the rapid build-up of pressure within the oral cavity, resulting in a drop of transglottal pressure; the further back the occlusion, the more difficult it is to maintain voicing. This allows for the reconstruction of a uvular order of consonants that used to comprise three stops: aspirated $/ \mathrm{q}^{\mathrm{h}} /$, unvoiced $/ \mathrm{q} /$, and voiced $/ \mathrm{G} /$. These uvular consonants may originate in velar+/r/ clusters, as is the case in Lizu (Chirkova 2008); but at present it is still too early to tell. (On the diversity of plausible origins for uvulars, see the example of Zhongu Tibetan: Sun 2003:782-783.)

This is of course not to say that the fricative /s/ of presentday Yongning $\mathrm{Na}$ is to be analysed synchronically as a $/ \mathrm{G} /$ phoneme: $/ \mathrm{b} /$ is definitely a fricative, not a stop. In the present state of our knowledge of $\mathrm{Na}$ and the languages most closely related to it, it is not possible to exclude the possibility that the present-day /s/

\footnotetext{
${ }^{7}$ Liberty Lidz's inventory of phonemes actually includes a voiced uvular stop, /G/. This phonemic unit is not present in the dialect studied here: the word for 'god, spirit', which has a /G/ initial in L. Lidz's data (from the village of Luòshuǐ 落水), is ${ }^{\mathrm{M}} \mathrm{gr}$.la/ in the data reported here (village of Píngjìng 平静).
} 
results from the evolution of an earlier non-uvular sound (e.g. French $/ \mathrm{s} /$ originates in an earlier $/ \mathrm{r} /$ ). Comparison with other Tibeto-Burman languages is required to shed light on this issue.

As a last observation about uvular consonants in Yongning $\mathrm{Na}$, the fricative $/ \mathrm{s} / \mathrm{shows}$ signs of weakening, being sometimes realised close to a velar $[\mathrm{\gamma}]$ in front of open vowels, and close to a labial-velar $[\mathrm{w}]$ in front of the rounded vowel /u/. The syllables / ьu/ and $/ \mathrm{u} /$ - the latter realised as [wu] - appear to be confused by some of the younger speakers; this has not yet been verified by means of perception tests.

\subsection{Retroflex consonants}

Like Western Naxi, Yongning $\mathrm{Na}$ has (i) a contrast between dental and retroflex affricates, with a high functional load, and (ii) relatively marginal contrasts between dental and retroflex stops and nasals.

\subsubsection{Retroflex stops}

In Western Naxi, dental-retroflex pairs of sounds such as [ $\mathrm{t}$ ] and [ $t$ ] appear on a first approximation to be allophones of the same phoneme (e.g. only the combination [tw] is attested, not [tw], and conversely, only [ti] is attested, not [ti]) but they do contrast in one context: in front of the vowel /o/ (Michaud 2006, section 2). In Yongning $\mathrm{Na}$, the overall situation is similar, but there are contrastive dental-retroflex pairs in a greater number of contexts: in front of $/ \mathrm{i} /, / \mathfrak{x} /, / \mathrm{y} /$ and $/ \mathrm{u} /$. Examples are provided in Table 5. 
Phonemic and tonal analysis of Yongning Na / CLAO 37(2008) pp-pp

Table 5. Examples showing the phonemic status of retroflex stops.

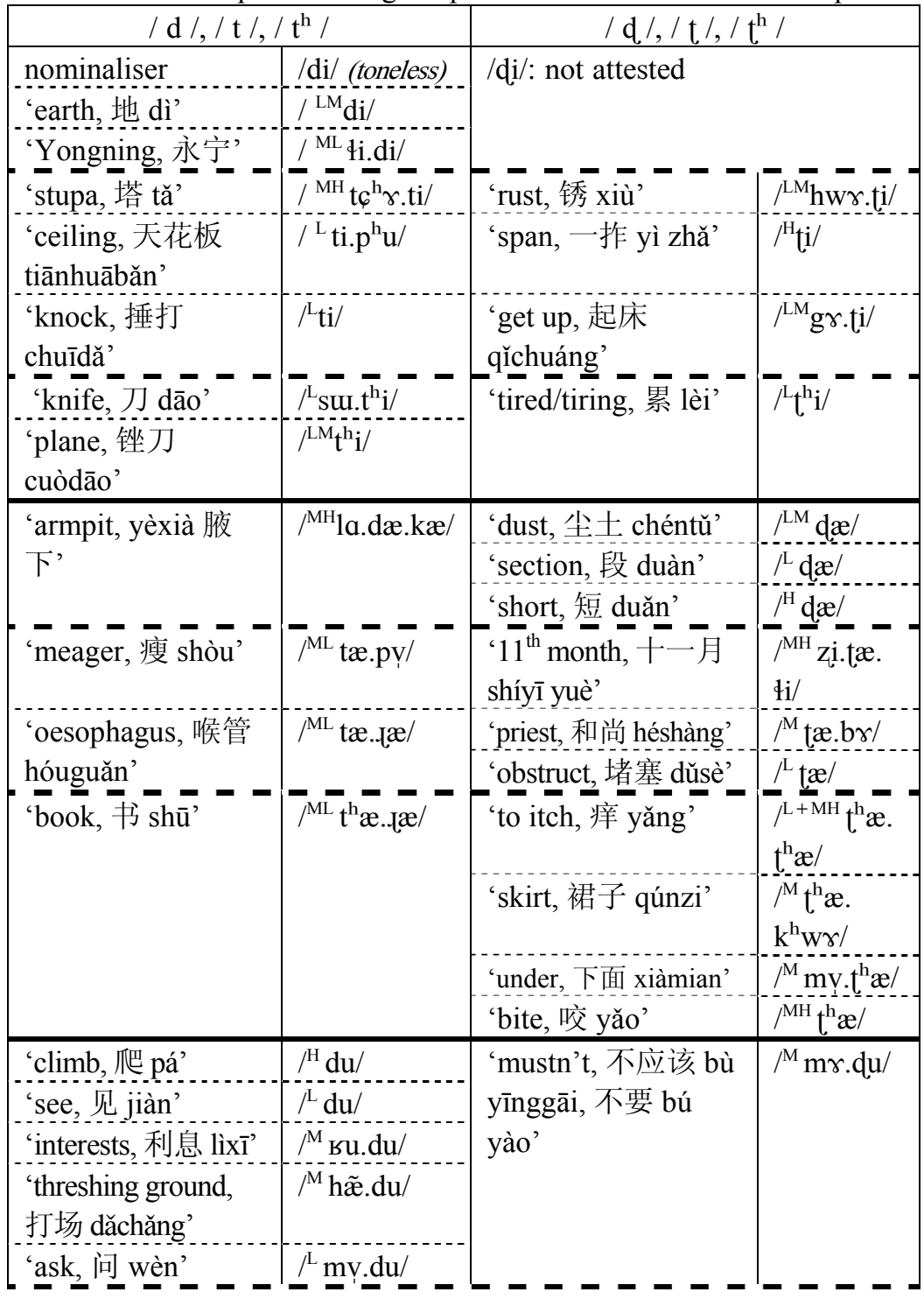




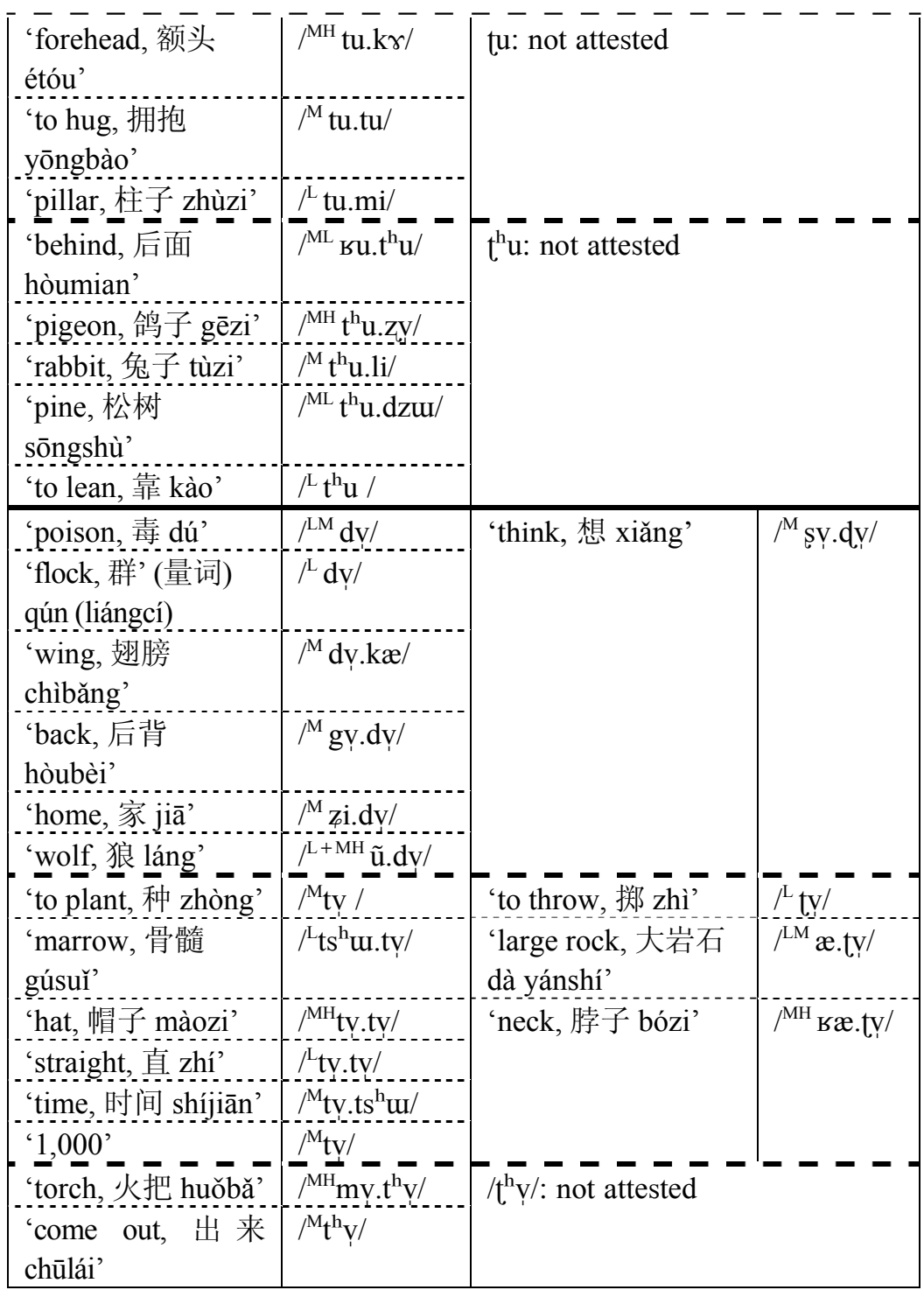


Phonemic and tonal analysis of Yongning Na / CLAO 37(2008) pp-pp

In Yongning $\mathrm{Na}$, there exist words that contain both retroflex and dental initials, e.g. / $^{\mathrm{MH}}$ tsa.ta/ 'sign, 记号 jìnà'. Therefore, the retroflex stop in words such as $/{ }^{\mathrm{M}} \mathrm{Sv} . \mathrm{d} \mathrm{d} /$ 'think' cannot be put down to a synchronic rule of retroflex harmony.

Combinations consisting of a dental stop followed by /æ/ (/dæ/, $\left./ \mathrm{tæ} /, / \mathrm{t}^{\mathrm{h}} æ /\right)$ are scarce. It might be that the vowel $/ æ /$ normally conditions a retroflex initial, and that the syllables with dental initials $+[æ]$ have a different underlying vowel, which gets changed to /æ/ by the influence of the other/æ/ in the word; this hypothesis appears well worth testing in future.

\subsubsection{Retroflex nasals}

Under the analysis proposed here, / $\eta /$ has phonemic status, contrasting with / $\mathrm{n} /$ in front of the rhyme $/ \mathrm{y} /$, e.g. /ny / in /LM $/ \mathrm{ny} .1 \mathrm{um} /$ 'bean 豆 dòu', / ny/ in / ${ }^{\mathrm{H}} \eta \mathrm{V} /$ ' (get to) know 知道 zhīdao, 得知 dézhī, and in $/{ }^{\mathrm{LM}} \eta \mathrm{V} / \mathrm{\prime}$ 'moth 蛙虫 zhùchóng'. The latter two words correspond to / no/ in the Western Naxi dialect of A Ser (Michaud 2006), i.e. to a syllable that also has a retroflex initial.

An alternative analysis is possible: under that analysis, the retroflex nasal $[\eta]$ of Yongning $\mathrm{Na}$ would not be phonemic, but would be an allophone of $/ \mathrm{n} /$, the combination of $/ \mathrm{n} /$ with the retroflex approximant rhyme / $\mathrm{d}$ (discussed in section 3.1.) being realised as [ $\left.\eta_{\mathrm{t}}\right]$ in the same way as $/ \mathrm{n} / \mathrm{t} / \mathrm{w} /$ is realised as [nu]. However, auditory impression suggests that the word at issue, '(get to) know 知道, 得知', has a rhyme $/ \mathrm{y} /$ rather than $/ \mathrm{d} /$, hence the decision to transcribe its phonemes as $/$ n $/$.

\subsubsection{The retroflex approximant / $/$ /}

The retroflex approximant / $t$ / is found in Yongning $\mathrm{Na}$ as an initial and also as a rhyme. The latter will be presented in section 3.1. As an initial, $/ \tau /$ is only found in the combinations $/ \mathfrak{l} /$ and

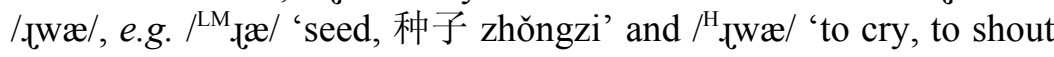


(of man or animal), 叫 jiào'. A hypothesis on the origin of this marginal phoneme is set out in section 2.4.

\subsection{The laterals / $1 /$ and / $1 /$, with a hypothesis about / $\downarrow$ /}

There are some minimal pairs for the opposition of $/ 1 /$ and $/ 4 /$ in Yongning $\mathrm{Na}$, such as $/{ }^{\mathrm{M}} \mathrm{li} /$ 'to look' vs. $/{ }^{\mathrm{M}} \mathrm{Hi} /$ 'month'. Phonetically, /1/ has a broad perimeter of allophonic variation. It involves some friction; this characteristic is at its clearest before the high front vowel /i/, but it is also observed before open vowels. In front of $/ \mathrm{w} /$, the voiced lateral tends to be realised as a weakened $[\xi]$, e.g. in the classifier for round objects - bowls, grains...-, ${ }^{\mathrm{M}} \mathrm{lu} /$. Phonetically, it would therefore be more adequate to transcribe it as [3] rather than [1]. Phonologically, it is economical to consider that the two laterals are distinguished solely by the feature of voicing, which also argues in favour of a notation as $/ \mathrm{b} /$. Phonemic notation as $/ 1 /$ rather than $/ 3 /$ for the voiced lateral is nonetheless retained here for the sake of simplicity.

These observations on the allophonic variation of /1/ lead to a hypothesis about the origin of the present-day / $t /$ initial of Yongning Na. It has been mentioned (§2.3.3) that this consonant phoneme only appeared in the syllables / aæ/ and / lwæ/. Synchronically, /ææ/ contrasts with /læ/, but the latter only appears (i) in borrowings (e.g. $/{ }^{\mathrm{MH}} 1 æ . t s u / /$ 'chilli peppers', from Southwestern Mandarin 辣子 [la.tso]), (ii) in the particle of accomplishment $/ \mathrm{l} /$, whose phonetic realisations, determined by the vowel of the following verb, include [læ], and (iii) in words where the /æ/ could possibly result from vowel harmony, e.g. $/{ }^{\mathrm{MH}}$ læ.ьæ/ 'raven'. Sporadic vowel harmony within disyllables is reported in several $\mathrm{Na} / \mathrm{Naxi}$ dialects: e.g., in Lijiang Naxi, 'pig food' has a colloquial form /ba」 hat/ (from /buJ/ 'pig' and /hat/ 'food'; see He and Jiang 1985:11). Hints that Yongning $\mathrm{Na} / \mathfrak{x} /$ is prone to harmony were mentioned in $\S 2.3 .1$. As for the syllable /fwæ/, there exists no lateral counterpart /lwæ/. It can therefore be 
Phonemic and tonal analysis of Yongning Na / CLAO 37(2008) pp-pp

hypothesised that present-day /£æ/ and / Łwæ/ originate in earlier $/ 1 æ /$ and $/ 1 w æ /$, which became phonetically closer to [.æ] and [-孔wæ], thus leaving empty the [læ] phonetic slot, which was then occupied by other syllables (listed in i-iii above). Roselle Dobbs (p.c.) signals the realisation of 'seed' as /læ/ in a dialect of Zuosuo (cp. Yongning /ææ/), an observation which is compatible with the present hypothesis. More comparative evidence will be necessary. Note that these diachronic reflections do not detract from the synchronic phonemic status of $/ \mathrm{t}$.

\section{OBSERVATIONS ABOUT THE RHYMES OF YONGNING NA}

The simple vowels of Yongning Na, /i/, /u/, /u/, / $/ \mathrm{/} /, / \mathfrak{m} /, / \mathrm{a} /$, $/ \mathrm{y} /, / \mathrm{l} /, / \tilde{\mathbf{1}} /, / \tilde{\mathrm{u}} /, / \tilde{\mathfrak{z}} /, / \tilde{\mathrm{a}} /, / \tilde{\mathrm{y}} /, / \tilde{\mathrm{l}} /$, tend to have an off-glide, though it is nowhere as strong as the on-glide of the complex rhymes, $/ \mathrm{ju} /$, $/ \mathrm{j} \gamma /$, /jæ/, /w $\gamma /$, /wæ/, /wa/, / $\tilde{\mathrm{w}} \gamma /$. Preliminary acoustic observations about the /i/ vowel are proposed in Michaud and Vaissière 2008.

The symbol $/ a /$ is used to transcribe the vowel of some grammatical words, which undergoes harmony with the vowel of the following syllable. It is present in kinship terms, e.g. $/{ }^{\mathrm{M}}$ o.mi/ 'mother', realised as [et mit]; /M ${ }^{\mathrm{M}} \mathrm{ma} / \mathrm{mother}$ (VOCATIVE)', [a- ma-1]; and $/^{\# \mathrm{MH}}$ ə.V/ 'uncle', [ $\left.\gamma-\mathrm{v} 1\right]$. It is probably also this vowel which is present in the particle $/{ }^{\mathrm{M}}$ la/ (described by L. Lidz as 'ACCOMPLISHED'), which likewise undergoes harmony with the vowel of the syllable that follows. Onset-less syllables have a soft onset (e.g. [ji], [wu]), with the exception of /o/, which usually has a glottal onset, and of nasal rhymes discussed at the end of section 3.2 .

Sections 3.1 and 3.2 address two sets of phenomena that are common in the geographic area: consonantal nuclei and nasals. 
Michaud A. / Cahiers de Linguistique - Asie Orientale 37(2008) pp-pp

\subsection{Consonantal nuclei}

In Yongning $\mathrm{Na}$, some consonantal sounds function as syllable nuclei. In the International Phonetic Alphabet they are called 'syllabic', because they function as a syllable nucleus. Fricative syllabics are an areal characteristic: in particular, they are common in neighbouring Yi languages, which belong to the Nasoid subgroup of Loloish (a.k.a. Ngwi; see Bradley 1979:70). The local dialect of Southwestern Mandarin also has a fricative allophone of $/ \mathrm{u} /$ in words such as 'lake', 湖 hú, pronounced close to [fv].

There are three sets of consonantal rhymes in Yongning Na:

(i) The voiced fricative / $/ \mathrm{V} /$ can only appear as a rhyme, not as an initial. On the whole, the friction for $/ \mathrm{y} /$ is much weaker than in Western Naxi. It has been mentioned at the outset of section 2 that the vowels of Yongning $\mathrm{Na}$ are somewhat diphthongised phonetically; in the case of $/ \mathrm{y} /$, the change in the course of the rhyme consists in part in formant movement, in part in a decrease in the amount of friction. Impressionistic listening suggests that the movement is towards a central articulation: $\left[\mathrm{v}^{\ominus}\right]$. Since friction noise is small even at the beginning of the rhyme, this $/ \mathrm{v} /$ could be described as close to an approximant, [v]. Martinet makes a distinction between fricatives proper, which have a firm articulation and are characterised by fricative noise, and spirants, which have a relaxed articulation, tending towards a vowel-like aperture (Martinet 1956:24, 1981). In terms of this distinction, unfortunately not yet taken up in the International Phonetic Alphabet, the articulation of $/ \mathrm{y} /$ in Yongning $\mathrm{Na}$ is spirant rather than fricative. After bilabial initials, $/ \mathrm{v} /$ has a tendency towards trilling - i.e. /bỵ/ is realised close to $[\mathrm{B}], / \mathrm{py} /$ close to $[\mathrm{p} \mathrm{B}]-$, though less markedly so than in Western Naxi.

(ii) As in Western Naxi, the vowel/u/ has fricative allophones after dental and retroflex fricatives and affricates. For instance, ${ }^{\mathrm{M}} \mathrm{ts}^{\mathrm{h}} \mathrm{w} /$ "hot" is realised [ts $\left.{ }^{\mathrm{h}} \mathrm{Z}_{1}\right], \mathrm{I}^{\# \mathrm{H}}$ dzuw/ "market, city" is realised 
Phonemic and tonal analysis of Yongning Na / CLAO 37(2008) pp-pp

[dżt]. It is customary to transcribe these sounds phonetically by means of the symbols coined by Chao Yuen-ren: [1] and [?], respectively. (The whole set proposed by Chao Yuen-ren consists of the plain apical vowel [1], the retroflex apical vowel [2], the rounded plain apical vowel [૫], and the rounded retroflex apical vowel [น]: see Pullum and Ladusaw 1986.)

(iii) A rhotic element is also present in some rhymes. Unlike Western Naxi dialects, whose vowel $/ \gamma^{\prime} /$ displays the considerable lowering of the third formant which is the telltale characteristic of rhotic vowels (as mentioned e.g. by Ladefoged and Maddieson 1996:313), Yongning $\mathrm{Na}$ does not have an [^] rhyme; its rhotic rhyme is here transcribed as / $\mathrm{l} /$, using the same symbol as for the consonantal unit described in \$2.3.3. Addition of the diacritic indicating syllabic status would yield $/ \mathrm{t} /$; this diacritic is omitted for the sake of visual clarity. As a rhyme, / $/$ / can appear on its own or preceded by a retroflex fricative or affricate. Examples of / $l$ / constituting a syllable on its own include lexical words, such as /LMi..l/ 'cheek', and a grammatical morpheme $/ \mathrm{d} /$, found in constructions such as /du _ $\mho^{/}$'<verb> a little', e.g. [du-lit lit] 'have a look, take a look' $\left({ }^{\mathrm{M}} \mathrm{li} / \mathrm{means}\right.$ 'to watch'). This syllable contrasts with onset-less $/ \mathrm{y} /$ (attested e.g. as a classifier:

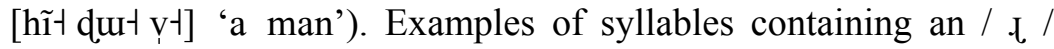
rhyme preceded by a retroflex affricate are presented in Table 6 , together with syllables made up of the same consonant followed by the rhyme $/ \mathrm{y} /$. 
Michaud A. / Cahiers de Linguistique - Asie Orientale 37(2008) pp-pp

Table 6. Some examples illustrating the phonemic contrast between $/ \mathrm{t} /$ and $/ \mathrm{y} /$ after retroflex fricatives and affricates.

\begin{tabular}{|c|c|c|}
\hline & $\mathrm{V}$ & $\mathrm{l}$ \\
\hline $\mathrm{ts}^{\mathrm{h}}$ & 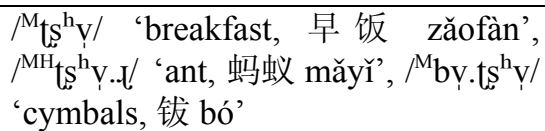 & ${ }^{\mathrm{MH}} \mathrm{t} \mathrm{s}^{\mathrm{h}} \mathrm{U} /$ ' 'lungs, 肺 fèi' \\
\hline ts & /MH mỵ.tsvy/'wrinkles, 皱纹 zhòuwén' & $\begin{array}{l}{ }^{\mathrm{H}} \text { tS.l / 'to cough, 咳嗽 } \\
\text { késou' }\end{array}$ \\
\hline \multicolumn{3}{|c|}{$\mathrm{dz}_{\mathrm{z}}:$ no contrasts observed } \\
\hline \multicolumn{3}{|c|}{ dental and retroflex stops $\left(\mathrm{t}^{\mathrm{h}} \mathrm{t} \mathrm{d}_{\mathrm{t}}^{\mathrm{h}} \mathrm{t} \mathrm{d}\right)$ : no contrasts observed } \\
\hline S & ${ }^{\mathrm{M}}{ }_{\mathrm{SV}} . \mathrm{dV} /$ 'think, 想 xiăng’ & 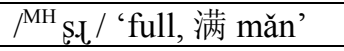 \\
\hline
\end{tabular}

The words for 'full' ( ${ }^{\mathrm{MH}}$ S.t $\left./\right)$, 'lungs' $\left({ }^{\mathrm{MH}}+\mathrm{ts}^{\mathrm{h}}{ }_{\mathrm{t}} /\right)$ and 'to cough' $\left({ }^{\mathrm{H}}\right.$ tS.t $\left./\right)$ have cognates with medial lip-rounding in the Western Naxi dialect of A Ser: these cognates are ${ }^{\mathrm{H}} \mathrm{s}^{\mathrm{w}} \mathrm{\gamma} /,{ }^{\mathrm{H}} \mathrm{tS}{ }^{\mathrm{hw}} \gamma \mathrm{\gamma}$ and ${ }^{\mathrm{M}} \mathrm{ts}^{\mathrm{w}} \gamma \mathrm{r}$, respectively, which contrast with unrounded syllables $/ \mathrm{s}^{2} /, / \mathrm{ts}^{\mathrm{h}} \mathrm{\gamma} /$ and $/ \mathrm{ts}^{2} /$ (Michaud 2006, section 3).

There is a difference across speakers for the word 'sickle': our main consultant realises it as /L $\mathrm{SV} . \mathrm{gv} /$, as does another consultant (in his late thirties), but two other speakers realise it as $/{ }^{\mathrm{L}} \mathrm{S} . \mathrm{g} . \mathrm{gV} /$, and a fifth speaker of the same hamlet as /L su.gy/. It may be that $/ \mathrm{L} \mathrm{sv} \cdot \mathrm{gv} /$ results from vowel harmony within the word; the contrast between $/ \mathrm{sv} /$ and /s.t may therefore be recent and somewhat tenuous. On the other hand, there is no reason to doubt the existence of the contrasts after retroflex affricates, which have been verified with several speakers.

Under the present analysis, the rhyme / $\downarrow$ / has a nasal counterpart, / $\tilde{\mathrm{l}} /$, which is discussed in the next section.

\subsection{Nasal rhymes}

The synchronic and diachronic analyses concerning the oral versus nasal contrasts after $/ \mathrm{h} /$ in the Naxi dialect of Fengke, at the 
border between the 'Western Naxi' and the 'Eastern Naxi/Na' dialect areas (Michaud 2006, section 1), appear to apply to the Yongning $\mathrm{Na}$ data as well. The Yongning $\mathrm{Na}$ data are somewhat more complex, however. Yongning $\mathrm{Na}$ has a larger inventory of nasal rhymes than Fengke Naxi: it comprises $/ \tilde{1} /, / \tilde{\mathrm{y}} /, / \tilde{\mathrm{a}} /, / \tilde{\mathfrak{x}} /, / \tilde{\mathrm{w}} \gamma /$, $/ \tilde{\mathrm{u}} /$, and $/ \tilde{\mathrm{t}} /$. The first five are found exclusively after $/ \mathrm{h} /$, where they contrast neatly with their non-nasal counterparts: see Table 7 . Phonetically, $/ \mathrm{h} /$ in front of oral rhymes is realised with a friction source at a point in the vocal tract determined by the following vowel, e.g. palatal before /i/ and labial-dental before $/ \mathrm{v} /$ (hence [çi] and [fv]). In front of nasal rhymes, $/ \mathrm{h} / \mathrm{is}$ nasalised; the lowered velum prevents the buildup of intra-oral pressure required for a strong friction noise.

Table 7. Examples of syllables with initial $/ \mathrm{h} /$ that are part of a correlation of

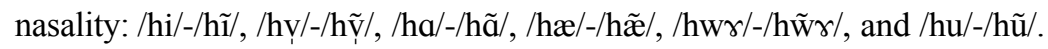

\begin{tabular}{|c|c|}
\hline oral rhyme & nasal rhyme \\
\hline$/{ }^{\mathrm{MH}} \mathrm{hi} /$ 'tooth, 牙齿 yáchǐ' & $\begin{array}{l}\text { /MH hĩ/ 'man', 人 rén; homophone: } \\
\text { 'to stand, 站 zhàn' }\end{array}$ \\
\hline $\begin{array}{l}\text { /Mhy/ 'happy; to like, 高 兴 } \\
\text { gāoxìng, 喜欢 xĭhuan' }\end{array}$ & 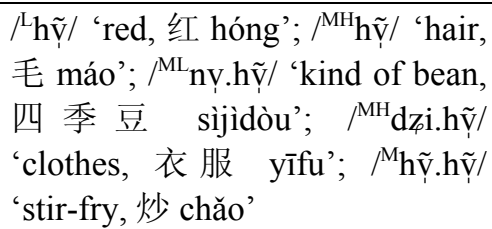 \\
\hline${ }^{\mathrm{MH}} \mathrm{ha} /$ 'food, 饭 fàn' & /MH hã / 'night, 夜 yè' \\
\hline $\begin{array}{l}\text { /Mhæ/ 'Chinese, 汉 hàn’; }{ }^{\mathrm{MH}} \mathrm{h} æ / \\
\text { 'lime, 石 灰 shíhuî'; / }{ }^{\mathrm{M} h æ . p \gamma /} \\
\text { 'plait, 辡子 biànzi' }\end{array}$ & 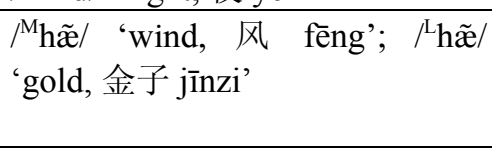 \\
\hline $\begin{array}{l}\text { /Ma.hwr/ 'yesterday evening, 昨 } \\
\text { 晚 zuówăn' }\end{array}$ & /'hwwr/ 'late, 迟 chí' \\
\hline $\begin{array}{l}\text { / }{ }^{\mathrm{M} h u /} \text { 'wait, 等 děng'; /MH hu.mi/ } \\
\text { 'stomach, 胃 wèi' }\end{array}$ & $\begin{array}{l}\text { /hũ/ 'eight, } 8 \text { '; /Mũ/: imperative } \\
\text { of 'to go' }\end{array}$ \\
\hline /hw/ 'went' & (no nasal counterpart) \\
\hline
\end{tabular}


Note that /hi/ contrasts with / $\mathrm{i}$ i/, e.g. in / ${ }^{\mathrm{M}}$ ci.lu// 'paddy': see end of section 2.1.

There also exist two types of onset-less nasal syllables: / $\tilde{u} /$ contrasts with $/ \mathrm{u} /$, and $/ \tilde{\mathrm{x}} /$ with $/ \mathrm{d} /$. Examples of $/ \mathrm{u} /$ (realised with a glide onset, [wu]) include $/ \mathrm{H} u /$ 'hard, 硬 yìng'; examples of $/ \tilde{\mathrm{u}} /$

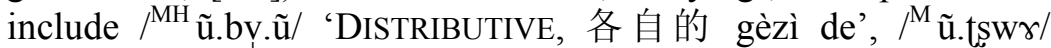
'mosquito' and $/^{\mathrm{L}+\mathrm{MH}} \tilde{u} . d v /$ ' 'wolf'. Lă Míngqīng 喇明清 and Roselle Dobbs (p.c.) provide an additional example: / ${ }^{\mathrm{u}} \mathrm{u} . \mathrm{zu} /$, 'agate, 玛瑙 mánăo'. As for $/ \tilde{\mathfrak{y}} /$, only one item has been found so far, but it is a very common word: 'bone', $/{ }^{\mathrm{MH}} \tilde{\mathrm{l}} /$, which also has the meaning of 'stem, 杆 găn'. Notation as a nasal rhotic vowel, / $\tilde{\partial} \%$, could also be acceptable; the symbol $/ \tilde{\mathrm{t}} /$ was chosen because the vowels transcribed as $/ \mathrm{I} /$ and $/ \tilde{\mathrm{e}} /$ have phonetic similarities and plausibly stand in a relation of structural contrast. (Examples of $/ \mathrm{d} /$ were provided in section 3.1.)

Onset-less nasalised syllables other than $/ \tilde{\mathrm{u}} /$ and $/ \tilde{\mathrm{t}} /$ still constitute a grey area of Yongning $\mathrm{Na}$ phonemics. The nasalised

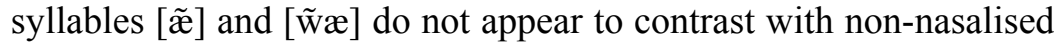
counterparts: for instance, 'copper' appears to be consistently nasalised phonetically $\left(\left[{ }^{\mathrm{MH}} \tilde{\mathfrak{x}}\right]\right)$; 'chicken' is often nasal ([ $\left.\left.{ }^{\mathrm{LM}} \tilde{\mathfrak{x}}\right]\right)$, but some oral realisations $\left(\left[{ }^{\mathrm{LM}} \mathfrak{x}\right]\right)$ were also observed; native speaker judgments suggest that these two words are in fact segmentally identical. 'To swell (e.g. of belly, of an injury), 肿 zhǒng, 胀 zhăng' is pronounced $\left[{ }^{\mathrm{M}} P \tilde{\mathrm{w}} \mathrm{]}\right]$ : the syllable always has a glottalised onset, and is audibly nasalised. Cross-dialect comparison does not reveal any nasal element: the cognate of Yongning $\mathrm{Na}\left[{ }^{\mathrm{M}}\right.$ ? $\tilde{\mathrm{w}}$ ] in the Western Naxi dialects is a simple $/{ }^{\mathrm{M}} \mathrm{u} /$ (Pinson 1998:107, and Hé Xuéguāng 和学光, p.c.). The third and last of these problematic onset-less nasalised syllables is [a] [ãa, which is occasionally nasalised, though with some intra-speaker variability. Further investigation into these nasal phenomena may reveal that the nasality of these syllables has to do with their tendency to have a glottal onset: it would then be an instance of the connection 
Phonemic and tonal analysis of Yongning Na / CLAO 37(2008) pp-pp

between nasality and glottality which Matisoff (1975) described under the name of 'rhinoglottophilia'. A working hypothesis is that the nasality of these syllables is not distinctive, and that they can be analysed simply as /æ/, /wæ/ and /a/, respectively.

\section{AN ANALYSIS OF THE TONE SYSTEM}

Like all the Naxi/Na dialects documented to date, Yongning Na makes use of three tonal levels: H(igh), M(id) and L(ow). Unlike Western Naxi, which has a syllable-tone system - one tone per syllable - with only a few processes of tonal change (Michaud and He Xueguang 2007), tones in $\mathrm{Na}$ are not lexically associated with individual syllables. Each lexical item has a tonal pattern (or, said differently, belongs in a tonal class); the way this tonal pattern attaches to syllables is determined by a set of association rules. The phonological notation used here therefore indicates tone by a superscript to the left of the word, instead of an indication for each syllable. Notations of the surface (phonetic) patterns classically rely on Chao tone letters.

The present analysis of the tones of Yongning $\mathrm{Na}$ borrows concepts from 'autosegmental' models of tone, which were originally developed for Subsaharan tone systems. The choice of these descriptive concepts is motivated by language-internal evidence; it is by no means dictated by a priori theoretical commitments (for a brief overview of the typological diversity of tone systems, see section 2 of Michaud 2008).

\subsection{The four tones of verbs}

Table 8 presents the four basic tonal classes of verbs including stative verbs, such as '(to be) large'. 
Michaud A. / Cahiers de Linguistique - Asie Orientale 37(2008) pp-pp

Table 8 . The four basic tonal classes of verbs in $\mathrm{Na}$, and their behaviour in several environments.

\begin{tabular}{|c|c|c|c|c|}
\hline in isolation & {$[\mathrm{M}]$} & {$[\mathrm{M}]$} & [LM] & {$[\mathrm{MH}]$} \\
\hline analysis & $\mathrm{H}$ & M & $\mathrm{L}$ & MH \\
\hline example & 'to eat' & 'to look' & 'to strike' & 'to bite' \\
\hline PROH & M.H & M.M & M.L & M.MH \\
\hline example & $\left.\left[\mathrm{t}^{\mathrm{h}} \mathrm{a}-\mathrm{dzu}\right\rceil\right]$ & {$\left[\mathrm{t}^{\mathrm{h}} \mathrm{a}-\mathrm{li}-1\right]$} & {$\left[\mathrm{t}^{\mathrm{h}} \mathrm{a}-\mathrm{d} \omega \mathrm{u} J\right]$} & {$\left[\mathrm{t}^{\mathrm{h}} \mathrm{a}-\mathrm{t}^{\mathrm{h}} \mathfrak{x} 1\right]$} \\
\hline NEG & M. $\underline{H}$ & M.M & M.L & M.MH \\
\hline example & [mrt dzul] & [mrtlit] & {$[\mathrm{m} \gamma \mathrm{dzi} J]$} & {$\left[\mathrm{mrt} \mathrm{t}^{\mathrm{h}} \mathfrak{1} 1\right]$} \\
\hline PRF & M.H.L & M.M.M & M.L.L & M.M.H \\
\hline example & [lət dzul za]] & [lot lit zəł] & [loł dzi」 zə]] & [lo- thæ才 zol] \\
\hline
\end{tabular}

$\mathrm{PROH}=$ prohibitive NEG $=$ negative marker; $\mathrm{PRF}=$ perfect

Examples include:

H: /dzu/ 'eat'; /i/ 'do'; /tșh $\mathfrak{h}$ / 'wash'; /hu/ 'wait'; /si/ 'walk'; /zuw/ 'heavy'

M: /li/ 'watch'; /hwæ/ 'buy'; /tr/ 'pull'; /bi/ 'go'; /ki/ 'give'; / $\mathrm{sg}^{\mathrm{h}} \mathrm{wæ} /$ 'rot'; /sæ/ 'long'/

L: /dzi/ 'cut'; /bæ/ 'sweep'; /tci// 'write'; /tsh w/ 'arrive'; /zi/ 'bring'; /dzu/ 'sit'; /ha/ 'deep'

MH: /th $æ$ / 'bite'; /la/ 'strike'; /t ${ }^{\mathrm{h}} \mathrm{i} /$ 'lose'; /hĩ/ 'stand'; /mi/ 'push'; /tha/ 'sharp, 锋利 fēnglì'

When a verb is preceded by the negation, the tone pattern attaches to the verb itself, whereas the negation receives $M$, by default (same for the prohibitive as for the negation). In the perfect (PRF), the first morpheme, $/ 1 \partial /$, receives $\mathrm{M}$ by default; the tone pattern attaches to the verb; if this pattern is complex (MH), the third morpheme hosts its last level (i.e. H); if this pattern is simple, 
Phonemic and tonal analysis of Yongning Na / CLAO 37(2008) pp-pp

it is copied onto the third morpheme, yielding $\mathrm{L}$ after $\mathrm{L}$ and $\mathrm{M}$ after M. As for the M.H.L sequence observed in the perfect of verbs with a lexical $\mathrm{H}$ tone, it results from a tone rule of Yongning $\mathrm{Na}$ whereby a $\mathrm{H}$ tone can only be followed by $\mathrm{L}$ within a phonological word.

In view of the fact that $M$ serves as the default level in the process of tone association, M-tone words could be analysed as having 'zero' tone. However, M-tone words need to be distinguished from toneless words - words that are altogether devoid of tone, such as the possessive, $/ \mathrm{bv} /$, mentioned in $\S 4.2$. It is admittedly possible to analyse / $\mathrm{M} /$ as 'zero' tone, and to distinguish this 'zero' tone from the absence of tone; at the present stage, however, it appears simpler to retain the label $/ \mathrm{M} /$.

In addition to the four tones $\mathrm{H}, \mathrm{M}, \mathrm{L}$ and $\mathrm{MH}$, the verb 'sell', $/ t c^{\mathrm{h}} \mathrm{i} /$, is an exceptional case within the $\mathrm{M}$ category, behaving like $\mathrm{H}$ in certain environments; two exceptional cases in the L category have also been observed, 'drink' / $/ \mathrm{h}$ w/ and 'speak'/zw $/$ /, behaving unlike other L-tone verbs in some of the contexts.

\subsection{The five tones of monosyllabic nouns}

Table 9 presents a phonological analysis of the tones of monosyllabic nouns in $\mathrm{Na}$.

Table 9. The tones of monosyllabic nouns in $\mathrm{Na}$.

\begin{tabular}{|l|l|l|}
\hline tonal analysis & \multicolumn{2}{|l|}{ example } \\
\hline $\mathrm{M}$ & ${ }^{\mathrm{M}} \mathrm{la}$ & 'tiger' \\
\hline $\mathrm{L}$ & ${ }^{\mathrm{L}} \mathrm{k}^{\mathrm{h}} \mathrm{Y}$ & 'dog' \\
\hline $\mathrm{LM}$ & ${ }^{\mathrm{LM}} \mathrm{bu}$ & 'pig' \\
\hline $\mathrm{MH}$ & ${ }^{\mathrm{MH}} \mathrm{hwr}$ & 'cat' [vocative only] \\
\hline \#H & ${ }^{{ }^{H}}$ zुwæ & 'horse' \\
\hline
\end{tabular}


The transcription $\# \mathrm{H}$ indicates a 'floating' $\mathrm{H}$ tone: the 'pound' symbol, \#, stands for the end of the lexical word; this $\mathrm{H}$ tone can only be realised after the end of the morpheme, as will be exemplified below. In addition, there exist two contour tones on monosyllabic nouns, $\mathrm{LM}$ and $\mathrm{MH}$, which surface as such in isolation ([bul] 'pig', [ł⿳亠1] 'brains').

Evidence for the analysis in Table 9 comes from the behaviour of these nouns in morphological derivations and in syntactic constructions. Table 10 provides information on the tones on nouns (i) in isolation, (ii) when followed by the toneless possessive particle /bv/, and (iii) when followed by the copula $/{ }^{\mathrm{L}} \mathrm{ni} /$. The '+' sign in Table 10 indicates morpheme boundaries.

Table 10. The tonal behaviour of Na monosyllabic nouns in isolation, when followed by the possessive (POSS), and when followed by the copula (COP).

\begin{tabular}{|l|l|l|l|l|l|}
\hline \multicolumn{2}{|l|}{ example } & tone & in isolation & + POSS & $+\mathrm{COP}$ \\
\hline${ }^{\mathrm{L}}$ la & 'tiger' & $\mathrm{M}$ & $\mathrm{M}$ & $\mathrm{M}+\mathrm{M}$ & $\mathrm{M}+\mathrm{L}$ \\
\hline${ }^{\mathrm{L}} \mathrm{k}^{\mathrm{h}} \mathrm{Y}$ & 'dog' & $\mathrm{L}$ & $\mathrm{M}$ & $\mathrm{L}+\mathrm{M}$ & $\mathrm{L}+\mathrm{LM}$ \\
\hline${ }^{{ }^{\mathrm{H}}}$ zwæ & 'horse' & \#H & $\mathrm{M}$ & $\mathrm{M}+\mathrm{M}$ & $\mathrm{M}+\mathrm{H}$ \\
\hline${ }^{\mathrm{MH}} \mathrm{hwr}$ & 'cat' & $\mathrm{MH}$ & $\mathrm{MH}$ & $\mathrm{M}+\mathrm{H}$ & $\mathrm{M}+\mathrm{H}$ \\
\hline${ }^{\mathrm{LM}} \mathrm{bu}$ & 'pig' & $\mathrm{LM}$ & $\mathrm{LM}$ & $\mathrm{L}+\mathrm{M}$ & $\mathrm{L}+\mathrm{M}$ \\
\hline
\end{tabular}

In isolation, the three non-contour tones, $/ \mathrm{M} /, / \mathrm{L} /$ and $/ \mathrm{H} /$, neutralise to $[\mathrm{M}]$. The $/ \mathrm{HH} /$ tone cannot manifest itself over a single syllable: it can only associate after the lexical word that carries it. This accounts for its realisation as $[\mathrm{M}]$ in isolation. On the other hand, it is not clear why /L/ surfaces as [M]: this may have to do with the prohibition of all-L phonological words (and a fortiori all$\mathrm{L}$ utterances) in $\mathrm{Na}$, but for verbs this is remedied by adding a postlexical $\mathrm{M}$ tone, so that $/ \mathrm{L} /$ verbs surface as $[\mathrm{LM}]$ in isolation. It is not clear at this stage why/L/ nouns do not likewise surface as 
Phonemic and tonal analysis of Yongning Na / CLAO 37(2008) pp-pp

[LM]; at the present stage of the analysis, there appear to be clear differences between the tones of nouns and those of verbs.

When the possessive /bv/ is added after the noun, yielding, e.g., [bu」 by $\left.{ }^{\prime}\right]$ 'of the pig', the tone assignment process is simple:

- contours unfold over the two syllables of the resulting combination: $\mathrm{LM}$ yields $\mathrm{L}+\mathrm{M}$, $\mathrm{MH}$ yields $\mathrm{M}+\mathrm{H}$

- non-contour tones $(\mathrm{M}, \mathrm{L}$ and $\# \mathrm{H})$ do not affect the second syllable, which surfaces with default $[\mathrm{M}]$; as for the first syllable, /M/ simply yields $[\mathrm{M}]$, /L/ simply yields $[\mathrm{L}]$, and /\#H/ yields [M] for the same reason as in isolation - viz. because the following morpheme cannot host the floating $\mathrm{H}$ tone.

This last point offers crucial evidence for the distinction between contours (/LM/ and $/ \mathrm{MH} /$ ) on the one hand and the floating $\mathrm{H}$ tone $(/ \mathrm{HH} /)$ on the other. The second part of a contour is realised on the possessive; the floating $\mathrm{H}$ tone is not. The interpretation proposed is that the possessive particle cannot provide anchorage for a tone. Two levels of description need to be distinguished: underlying tones (tone patterns), and surface tone levels. The possessive cannot provide anchorage for a tone, but it can host a tone level that is part of a tone anchored to a preceding syllable. The MH contour tone in Table 10 has a stable phonological anchorage: it is anchored to the syllable preceding the possessive. From there, the second part of the contour can be projected onto the possessive - a process of contour unfolding which is distinct from processes of tonal anchoring. On the other hand, the floating $\mathrm{H}$ tone initially lacks anchorage, and the possessive particle is unable to provide such anchorage; the $\mathrm{H}$ tone therefore remains unattached (and is deleted).

When the noun is followed by the copula, e.g. [bu」 yit] '[that] is [a/the] pig', tonal association takes place as follows: the copula has a lexical/L/ tone; this /L/ tone surfaces as such, on the copula, unless overridden by a tonal level projected by the noun. 
Michaud A. / Cahiers de Linguistique - Asie Orientale 37(2008) pp-pp

There are three tones that can project their last level onto the copula, thus chasing away its lexical L tone: the two contours (LM and $\mathrm{MH}$ ), which unfold over the disyllabic combination, in the same way as when the possessive /bv/ is added after a noun; and the floating $\mathrm{H}$ tone, $/ \mathrm{HH} /$, which gets anchored to the copula. As for the remaining two tones, $/ \mathrm{M} /$ and $/ \mathrm{L} /$, they do not affect the copula, which retains its $/ \mathrm{L} /$ tone. An added complexity is that the $\mathrm{L}+\mathrm{L}$ sequence cannot surface as such, due to a general prohibition against all-L phonological words (and a fortiori all-L utterances) in $\mathrm{Na}$. The all-L sequence is avoided by post-lexical addition of a final $\mathrm{M}$ tone, which modifies $\mathrm{L}+\mathrm{L}$ to $\mathrm{L}+\mathrm{LM}$, e.g. $\left.\left[\mathrm{k}^{\mathrm{h}} \mathrm{v}\right\rfloor \mathrm{yil}\right]$ '[that] is [a/the] dog'.

\subsection{The tones of disyllables in Na: a static view}

Table 11 presents the tonal classes of disyllables in Na. The pound sign, \#, refers to the boundary of the word. The dollar sign, $\$$, is explained below, §4.3.2. The table does not include /LML/, a tone pattern attested by one single word, which will be discussed in $\S 4.3 .3$. The tones which appear to correspond to those of monosyllables will be discussed first (§4.3.1.), followed by those which are restricted to di- and polysyllables (§4.3.2.). 
Table 11. The tonal classes of disyllabic nouns in Na. The thick horizontal line separates the five tonal classes that correspond to those of monosyllabes (above the line) from the other five. The 'dollar' sign, $\$$, stands for the end of the phonological phrase: see $\S 4.3 .2$ for explanations. The 'plus' sign, + , demarcates the disyllabic noun from following morphemes.

\begin{tabular}{|c|c|c|c|c|c|c|}
\hline \multirow{2}{*}{$\begin{array}{l}\text { tone: } \\
\text { phonetics } \\
\text { in } \\
\text { isolation }\end{array}$} & \multirow{2}{*}{$\begin{array}{l}\text { tone: } \\
\text { phono- } \\
\text { logical } \\
\text { category }\end{array}$} & \multirow{2}{*}{$\begin{array}{l}\text { tone: } \\
\text { +Poss }\end{array}$} & \multirow{2}{*}{$\begin{array}{l}\text { tone: } \\
+ \text { COP }\end{array}$} & \multicolumn{3}{|l|}{ example } \\
\hline & & & & phonology & $\begin{array}{l}\text { phonetics in } \\
\text { isolation }\end{array}$ & meaning \\
\hline [M.M] & M & $\mathrm{M} . \mathrm{M}+\mathrm{M}$ & $\mathrm{M} . \mathrm{M}+\mathrm{L}$ & / ${ }^{\mathrm{M}}$ 4i.mi/ & [ $\mathrm{fi}-\mathrm{mi}-1]$ & 'moon' \\
\hline [L.LM] & $\mathrm{L}$ & L.L + M & L.L $+\mathrm{M}$ & $/{ }^{\mathrm{L}} \mathrm{k}^{\mathrm{h}} \mathrm{y} \cdot \mathrm{mi} /$ & $\left.\left[\mathrm{k}^{\mathrm{h}} \mathrm{v}\right\rfloor \mathrm{mi} \lambda\right]$ & 'she-dog, bitch' \\
\hline [M.M] & $\# \mathrm{H}$ & $\mathrm{M} . \mathrm{M}+\mathrm{M}$ & M.M+H & / ${ }^{\# \mathrm{H}}$ ni.mi/ & [ni- mi-t] & 'sun' \\
\hline [M.MH] & $\mathrm{MH \#}$ & M.M+H & M.M+H & / ${ }^{\mathrm{MH} \#} \mathrm{hw \gamma} .1 \mathrm{i} /$ & [hwrtli1] & 'cat' \\
\hline [L.M] & LM & $\mathrm{L} . \mathrm{M}+\mathrm{M}$ & L.M + L & /LM bu.mi/ & $[\mathrm{bu}\rfloor \mathrm{mi} \dashv]$ & 'sow, female pig' \\
\hline [M.H] & HS & $\mathrm{M} . \mathrm{M}+\mathrm{M}$ & $\mathrm{M} . \mathrm{M}+\mathrm{H}$ & / ${ }^{\mathrm{H} \$}$ hwr.mi/ & [hwrt mi门] & 'she-cat' \\
\hline [L.M] & $\mathrm{LM}+\# \mathrm{H}$ & L.M+M & L.M $+\mathrm{H}$ & / ${ }^{\mathrm{LM}+\# \mathrm{H}}$ na.hĩ// & [na」hĩ-1] & 'Naxi' \\
\hline [L.MH] & $\mathrm{L}+\mathrm{MH}$ & L.M+H & L.M+H & / L+MH i.tş్/ & [i」 tșæ1] & 'waist' \\
\hline [M.L] & ML / L\# & M.L + L & M.L + L & / ${ }^{\mathrm{ML}}$ вu.dzu/ & [sut dzu」] & 'Tibetan' \\
\hline [M.H] & $\mathrm{MH} / \mathrm{H \#}$ & $\mathrm{M} . \mathrm{H}+\mathrm{L}$ & M.H+L & / ${ }^{\mathrm{MH}}$ ьæ.ty/ & [вæ- tүๆ] & 'neck' \\
\hline
\end{tabular}




\subsubsection{Five categories also found over monosyllables}

The first five categories in Table 11 appear to correspond to the five classes of monosyllables (Tables 9-10). However, these correspondences will need to be verified by the examination of morphological processes leading to the creation of disyllables: some of the disyllabic examples in the table can be analysed as consisting of a monosyllabic noun plus suffix $-e . g . /^{\mathrm{LM}}$ bu.mi/ 'sow', from $/{ }^{\mathrm{LM}} \mathrm{bu} /$ 'pig'- but the story behind the disyllabic 'sun' and 'moon' is more complex than simple synchronic derivation, and the second syllable is unlikely to be identical in origin to the female suffix found in 'sow'. The second syllable of 'cat', /li/, is not a productive suffix in the present stage of the language, and may never have been an independent morpheme. (The issue of derivation is taken up again in $\S 4.3 .4$.)

The tonal category transcribed as $/ \mathrm{MH \# /}$ (e.g. $/{ }^{\mathrm{MH} \#}$ hwr.li/ 'cat') is characterised by a contour, $/ \mathrm{MH} /$, that associates to the last syllable. The $\mathrm{H}$ part of the contour lands on a following syllable, if one is available, e.g. the copula. The first syllable receives a [M] tone; it is as yet uncertain whether this process consists in copying the tone of the second syllable, or in default association of a $\mathrm{M}$ tone. These processes yield [hwr-litil]], '...is [a/the] cat'.

When subjected to the simple manipulations reported above for monosyllables (addition of the possessive /by/, i.e. derivation, and addition of the copula, i.e. creating a sentence), the five sets of disyllables behave essentially like the monosyllables, as can be verified from a comparison of Tables 10 and 11. There is one complexity, however: / ${ }^{\mathrm{L}} \mathrm{k}^{\mathrm{h}} \mathrm{v} \cdot \mathrm{mi} / /$ 'dog' yields $\left.\left[\mathrm{k}^{\mathrm{h}} \mathrm{v}\right\rfloor \mathrm{mi}\right\rfloor \mathrm{ni}-$ ] 'is [a/the] dog, i.e. the copula loses its lexical/L/ tone. There is no obvious reason why the $/ \mathrm{L} /$ tone of the noun should cause this change: one would have expected a /L.L.L/ sequence (realised as $\left.\left.\left[\mathrm{k}^{\mathrm{h}} \mathrm{y}\right\rfloor \mathrm{mi}\right\rfloor \mathrm{gi} \lambda\right]$, following the addition of a post-lexical [M] to avoid an all-L phonological word). It may be that units of more than two syllables obey different rules from disyllabic units. 


\subsubsection{Five categories not found on monosyllables}

As for the five remaining tonal classes of disyllables, some can easily be analysed as the concatenation of the tones of two monosyllables. Such is the case of the word for 'Naxi', which is a calque from the Naxi language. The autonym of the $\mathrm{Na}$ is simply ${ }^{\mathrm{LM}} \mathrm{na} /$, 'the $\mathrm{Na}$ ', whereas that of the Naxi is disyllabic: / ${ }^{\mathrm{L}}{ }^{\mathrm{M}} \mathrm{hi} /$, where the second syllable means 'man, person'. ${ }^{8}$ This is close enough to allow for a loan-translation into the $\mathrm{Na}$ language: to their native word $/{ }^{\mathrm{LM}} \mathrm{na} /$, they add their own word for 'man', / ${ }^{\mathrm{H}} \mathrm{h} \tilde{\mathrm{i}} /$, yielding $/{ }^{\mathrm{LM}+\# \mathrm{H}}$ na.hĩ/, a disyllable with a complex tonal pattern, $/ \mathrm{LM}+\# \mathrm{H} /$, i.e. a $\mathrm{LM}$ contour plus a floating $\mathrm{H}$ tone.

The $/ \mathrm{L}+\mathrm{MH} /$ pattern probably results from the combination of a /L/-tone monosyllable with a /MH/-tone monosyllable.

Other patterns require more detailed explanations. The 'dollar' sign, \$, stands for the end of the phonological phrase: H\$ refers to a $\mathrm{H}$ tone that associates to the last syllable of the phonological phrase. The other syllables receive $\mathrm{M}$, by default. Thus, / ${ }^{\mathrm{HS}} \mathrm{kv} . \mathrm{si} /$ ' $\mathrm{flea}$ ' is realised as [kv- si门] in isolation, where the last syllable of the word is also the last syllable of the phonological phrase; adding the copula after this word yields [kv- sił ni $\mathrm{H}$ tone lands, not on the last syllable of the lexical word, but on the copula, which is the last syllable of the phonological phrase. Examples include: / ${ }^{\mathrm{HS}} \mathrm{m} v . \mathrm{Gu} /$, 'the heavens above'; $/{ }^{\mathrm{HS}} \mathrm{q}^{\mathrm{h}} \mathrm{y} \cdot \mathrm{d} z \mathrm{i} /$ 'hole, cavity, 窟㶻 kūlóng'; / ${ }^{\mathrm{HS}}$ dzæ.. ${ }^{\mathrm{h}} \mathfrak{H} /$ 'mud'; / ${ }^{\mathrm{HS}} \mathrm{kv} \cdot t s \mathrm{su} /$ 'nail, 指甲 zhíjiă'; / ${ }^{\mathrm{HS}}$ hu.mi/ 'stomach'; / ${ }^{\mathrm{HS}}$ ə.da/ 'father'; / ${ }^{\mathrm{HS}}$ hwa.q ${ }^{\mathrm{h}} \mathrm{v}$ / 'dusk'; / ${ }^{\mathrm{H}} 1 æ . \mathrm{ræ} /$ 'raven'; / ${ }^{\mathrm{H}} \mathrm{hw} \gamma \cdot \mathrm{p}^{\mathrm{h}} \mathrm{y} /$ 'tomcat, 公猫 gōngmāo'.

\footnotetext{
${ }^{8}$ The Naxi word for 'man' is transcribed as [cit] in Chinese publications (e.g. He and Jiang, op. cit., p. 21). The place of articulation of the fricative is in fact palatal rather than alveolo-palatal (less fronted than, e.g., Standard Mandarin [c]), hence its transcription as [ç] by Michailovsky et al. (2006), who analyse it phonemically as an allophone of $/ \mathrm{h} /$. For a detailed analysis of $/ \mathrm{h} /$-initial syllables in Naxi, see Michaud (2006).
} 
The word-formation processes that result in this $\mathrm{H} \$$ tone have not yet been elucidated.

The last two patterns in Table 11, [M.L] and [M.H], are open to (at least) two interpretations: either as /ML/ and /MH/ contours, respectively, associating with syllables left-to-right; or as defined solely in terms of the tone of their second and last syllable, i.e. /L\#/ and $/ \mathrm{H} \# /$, respectively, the first syllable receiving $[\mathrm{M}]$ by default. Thus, [ви- dzw」] 'Tibetan' can be analysed as $/^{\# \mathrm{~L}}$ Бu.dzu/ or $/{ }^{\mathrm{ML}}$ bu.dzu/. At present, no decisive evidence has been found in favour of one analysis over the other. An argument against the contour interpretation is that no [ML] contour ever appears on a monosyllable, unlike [LM] and [MH]. Decisive arguments in favour of one or the other of these two analyses may come from polysyllabic words. A working hypothesis is that trisyllabic [M.L.L] words such as the plural personal pronouns [njrł suJ kv」] (1PL EXCL), [ə† su」 ky」] (1PL INCL), [nuł su」 ky」] (2PL) and [ts $\left.\left.{ }^{\mathrm{h}} \mathrm{u}-\mathrm{suJ} \mathrm{ky}\right\rfloor\right](3 \mathrm{PL})$ fall into the same tonal class as disyllabic [M.L] words (this is reflected in the notation $/{ }^{\mathrm{ML}}$ nu.su.kv/ in Table 4 for 2PL). If this hypothesis is confirmed, the issue will be settled in favour of an interpretation of the [M.L] tone as $/ \mathrm{ML} / .{ }^{9}$ Pending further evidence, the tones at issue are transcribed as $/ \mathrm{ML} /$ and $/ \mathrm{MH} /$, respectively. Examples of the /ML/ category include: / ${ }^{\mathrm{ML}}$ ni. $\mathrm{p}^{\mathrm{h}} \mathrm{v} /$ 'frost, 霜 shuāng'; / ${ }^{\mathrm{ML}}$ gu.br/ 'temple'; / ${ }^{\mathrm{ML}}$ ьu.q ${ }^{\mathrm{h}} \mathrm{w} \gamma /$ 'head'; / ${ }^{\mathrm{ML}}$ ti.pi/ 'ear'; / ${ }^{\mathrm{ML}}$ bi.tç/ 'navel, 肚脐 dùqí'; / ${ }^{\mathrm{ML}} \mathfrak{x}$.mv/ 'elder brother/sister'; / ${ }^{\mathrm{ML}} \mathrm{p}^{\mathrm{h}} \mathrm{i} . \mathrm{li} /$ 'butterfly'; / ${ }^{\mathrm{ML}}$ da.i/ 'mule'; / ${ }^{\mathrm{ML}}$ su.dzu/ 'tree'. Examples of the /MH/ category include: / ${ }^{\mathrm{MH}} \mathrm{mv} . \mathrm{c}_{\mathrm{i}} /$ 'spark';

\footnotetext{
${ }^{9}$ Over three syllables, /ML/ yields [M.L.L] by left-to-right, one-to-one association of tonal levels to syllables, followed by the application of a basic rule of Yongning $\mathrm{Na}$ tonal phonology: within a phonological phrase, a tonal level cannot be surrounded by higher tonal levels. This rule prohibits MLM sequences: given the association of $\mathrm{M}$ to the first syllable of a three-syllable domain, and of $\mathrm{L}$ to the second, the third syllable can only receive L.
} 
Phonemic and tonal analysis of Yongning Na / CLAO 37(2008) pp-pp

/ ${ }^{\mathrm{MH}}$ njæ.bæ/ 'tear'; / ${ }^{\mathrm{MH}}$ вæ.tv/ 'neck'; / ${ }^{\mathrm{MH}}$ zu.mṿ/ 'child'; / ${ }^{\mathrm{MH}}$ ț.tv / 'hat'; / ${ }^{\mathrm{MH}}$ lu.pi/ 'finger'.

\subsubsection{A putative eleventh category: /LML/}

Lastly, there is one single lexical item which appears to have a LML pattern: / ${ }^{\mathrm{LML}}$ bu.ła/ 'boar, male pig, 种公猪 zhǒng gōngzhū'. In isolation, this word is realised as [bu」 lat], i.e. with the same tone pattern as [bu」 mit] 'sow' (underlyingly / ${ }^{\mathrm{LM}}$ bu.mi/). The noun 'boar' projects a $\mathrm{L}$ tone onto a following possessive particle, /by/, yielding [bu」 fał by J], instead of the L.M.M pattern that one would expect by analogy with 'sow': [bu」 mi- by-1]. It has been noted in $\S 4.3 .1$ that only contour tones (tones consisting of more than one level) can project their last tonal level tone onto the possessive particle; pursuing this line of reasoning, one is led to conclude that the L level on the possessive particle /by/ is due to the presence, on the noun, of a contour tone ending in a final L. This is the only word (out of a word list of some 2,000 items) which has this behaviour; moreover, there is cross-speaker variation for this item. A younger speaker $(\mathrm{F} 5)^{10}$ has it with a $/ \mathrm{L}+\mathrm{MH} /$ pattern: $/^{\mathrm{L}+\mathrm{MH}}$ bu.ta/, realised [bu」 ad1] in isolation; another speaker (M21), of the same generation as the main consultant (F4), provided another word, ${ }^{\mathrm{LM}} \mathrm{bu} . \mathrm{ts} \gamma /$, and refused [bu」la-1]. There is thus evidence for provisionally treating speaker F4's word for 'boar' as an exception, rather than as proving the existence of a LML tone.

\subsubsection{Reflections on morphological derivations}

In the simplest cases of suffixation, the suffix can be considered as toneless. For instance, the female suffix $/ \mathrm{mi} /$ is very likely to be cognate with the classifier $/ \mathrm{L}$ mi/ used for some animals

\footnotetext{
${ }^{10}$ Codes are assigned successively to all the language consultants who participate in fieldwork; this is intended to facilitate reference to the recorded data.
} 
(e.g. chicken); the classifier has a lexical L tone, evidenced by its behaviour when associated with numerals (e.g. [dut miJ], 'one'+CLASS); on the other hand, the suffix appears to be toneless, and the tonal pattern of the resulting disyllable is obtained by association of the tone of the root with the entire disyllable. A /LM/ tone yields [L.M]: / ${ }^{\mathrm{LM}} æ /$ 'chicken $>/{ }^{\mathrm{LM}} æ . \mathrm{mi} /$ 'hen, 母鸡 mǔji', realised as [æ」 mi-l]; / ${ }^{\mathrm{LM}} \mathrm{bu} /$ 'pig' > / ${ }^{\mathrm{LM}}$ bu.mi/ 'sow, 母猪 mǔzhū', realised as [bu」 mi-l]. A M-tone monosyllable yields a M-tone disyllable (surfacing with [M] on each syllable); and /L/ yields [L.L] (again with post-lexical addition of $\mathrm{M}$ to avoid an all-L sequence, hence [L.LM]): $/{ }^{\mathrm{L}} \mathrm{k}^{\mathrm{h}} \mathrm{v} /{ }^{\prime} \operatorname{dog}{ }^{\prime}>/{ }^{\mathrm{L}} \mathrm{k}^{\mathrm{h}} \mathrm{v} \cdot \mathrm{mi} /$ 'she-dog', realised as $\left.\left[\mathrm{k}^{\mathrm{h}} \mathrm{v}\right\lrcorner \mathrm{mi} \lambda\right]$. However, it may be misleading to think of these disyllables as the result of strictly synchronic morphological processes. Not all disyllables containing the female suffix are tonally regular: for instance, ${ }^{\# \mathrm{H}} \mathrm{zw} æ /$ 'horse' yields $/ \mathrm{L}$ zwæ.mi/ 'mare', instead of the expected ${ }^{\# H}$ zwæ.mi/, suggesting a complex diachronic scenario, perhaps involving an earlier derivation prior to suffixation. (The tonal behaviour of this word is also irregular in the related languages Shixing - E. Chirkova, p.c. - and Laze - my own data.) Other disyllables can hardly be analysed with certainty: the second syllable in / ${ }^{\# \mathrm{H}} \mathrm{ji} . \mathrm{mi} /$ 'sun' and / ${ }^{\mathrm{M}} \mathrm{ki} . \mathrm{mi} /$ 'moon' is not on a par with the feminine suffix in 'sow'.

\section{CONCLUDING REMARKS}

The above analyses are intended to advance our general knowledge of the phonemic system of Yongning Na. Although they aim to be relatively independent of any specific research purpose, they open perspectives for further research. From a synchronic point of view, the tonal system - more complex than that of Western Naxi - still raises issue well worth investigating. From a diachronic point of view, one of the phonemic observations is relevant to current debates: the presence or absence of uvular 
Phonemic and tonal analysis of Yongning Na / CLAO 37(2008) pp-pp

phonemes is somewhat paradoxically used by Sūn Hóngkāi 孙宏开 2001 among the criteria for the genetic subgrouping of languages of the area; the presence of uvulars in Yongning $\mathrm{Na}$ and not in Western Naxi supports the traditional view that such characteristics do not constitute a reliable basis for language classification. As for the project of reconstructing the main features of a common ancestor for $\mathrm{Na} / \mathrm{Naxi}$ dialects, their simple syllabic structure is a major obstacle. The segmental depletion of the syllable has proceeded even further in these languages than in Chinese. The task of reconstruction will therefore require data from other languages, for instance looking to Burmese cognates for hints on the reconstruction of final stops (G. Jacques, p.c.).

\section{REFERENCES}

BACOT Jacques (1913). Les Mosso, ethnographie des Mosso, leurs religions, leur langue et leur écriture, avec les documents historiques et géographiques relatifs à Li-kiang par Ed. Chavannes. Leiden : E.J. Brill.

BRADLEY David (1975). Nahsi and Proto-Burmese-Lolo. Linguistics of the Tibeto-Burman Area, 2(1), pp. 93-150.

BRADLEY David (1979). Proto-Loloish. London : Curzon Press.

CHAO Yuen-ren (1934). The non-uniqueness of phonemic solutions of phonetic systems. Bulletin of the Institute of History and Philology, Academia Sinica, 4(4), pp. 363-397.

CHAVANNES Edouard (1912). Documents historiques et géographiques relatifs à Li Kiang. T'oung Pao, 13(1-5), pp. 565-653.

CHIRKOVA Ekaterina (2008). Essential characteristics of Lizu, a Qiangic language of Western Sichuan. Paper presented at: Workshop on Tibeto-Burman languages of Sichuan, Academia Sinica, Taipei, Nov. 2008. 
Michaud A. / Cahiers de Linguistique - Asie Orientale 37(2008) pp-pp

GROS Stéphane (1996). Terres de confins, terres de colonisation : essai sur les marches sino-tibétaines du Yunnan à travers l'implantation de la Mission du Tibet. Péninsule, 33(2), pp. 147-211.

GUŌ Dàliè 郭大烈 and HÉ Zhìwǔ 和志武 (1994 [2nd ed. 1999]). Nàxīzú shi 纳西族史 [A History of the Naxi people]. Chóngqìng : Sìchuān Mínzú Chūbănshè 四川民族出版社.

HÉ Jírén 和即仁 and JIĀNG Zhúyí 姜竹仪 (1985). Nàxīyǔ jiănzhi 纳西语 简志 [A Brief Monography on the Naxi Language]. Beijing : Mínzú Chūbănshè 民族出版社 (Zhōngguó shăoshù mínzú yǔyán jiănzhì cóngshū 中国少数民族语言简志丛书).

HYMAN Larry and VANBIK Kenneth (2002). Tone and stem2 formation in Hakha Lai. Linguistics of the Tibeto-Burman Area, 25, pp. 113121.

JIĀNG Zhúyí 姜竹仪 (1993). Nàxīyǔ dōngbù hé xībù fāngyán yúfă yìtóng gàishù 纳西语东部和西部方言语法异同概述 [An Outline of the Grammatical Similarities and Differences between Eastern and Western Dialects of Naxi]. Minzú yǔwén 民族语文, 4, pp. 43-50.

LĀMǍ Zīwò 拉玛兹偓 (1994). Nàmùyīyǔ zhīshǔ yánjiū 纳木依语支属研 究 [About the classification of the Namuyi language]. Mínzú yǔwén 民族语文, 1, pp. 50-60.

LADEFOGED PETER and MADDIESON Ian (1996). The sounds of the world's languages. Oxford : Blackwell.

LĀTĀMĪ Dáshí 拉他咪达石 (2006). Mósuō shèhuì wénhuà yánjiū lùnwénji 摩梭社会文化研究论文集(1960-2005) [A collection of articles about Mosuo society and culture]. Kūnmíng 昆明: Yúnnán Dàxué Chūbănshè 云南大学出版社.

LIDZ Liberty (2006). A synopsis of Yongning Na (Mosuo). Presentation at the 39th International Conference on Sino-Tibetan Languages 
Phonemic and tonal analysis of Yongning Na / CLAO 37(2008) pp-pp

and Linguistics, University of Washington, Seattle; full paper available at: http://depts.washington.edu/icstll39/participants.html

LIDZ Liberty (2007). Evidentiality in Yongning $\mathrm{Na}$ (Mosuo). Linguistics of the Tibeto-Burman Area, 30(2), pp. 45-87.

LIDZ Liberty (to appear). A descriptive grammar of Yongning $\mathrm{Na}$ (Mosuo). Ph.D., University of Texas, Austin.

MARTINET André (1956). La Description phonologique avec application au parler franco-provençal d'Hauteville (Savoie). Genève : Droz.

MARTINET André (1981). Fricatives and spirants. In : MALLIK Bhakti Prasad (ed). Suniti Kumar Chatterji commemoration volume. Burdwan, India : Burdwan University Press. Pp. 145-151.

MARTINET André (1990). La synchronie dynamique. La linguistique, 26(2), pp. 13-23.

MATISOFF James (1975). Rhinoglottophilia: the mysterious connection between nasality and glottality. In : FERGUSON Charles et al. (eds). Nasálfest: Papers from a Symposium on Nasals and Nasalization. Stanford : Stanford University. Pp. 265-87.

MICHAILOVSKY Boyd and MICHAUD Alexis (2006). Syllabic inventory of a Western Naxi dialect, and correspondence with Joseph F. Rock's transcriptions. Cahiers de linguistique - Asie Orientale, 35(1), pp. 3-21.

MICHAUD Alexis (2006). Three extreme cases of neutralisation: nasality, retroflexion and lip-rounding in Naxi. Cahiers de linguistique Asie Orientale, 35(1), pp. 23-55.

MICHAUD Alexis (2008). Tones and intonation: some current challenges. Proceedings of 8th International Seminar on Speech Production (ISSP'08), Strasbourg. http://halshs.archives-ouvertes.fr/halshs00325982/ 
Michaud A. / Cahiers de Linguistique - Asie Orientale 37(2008) pp-pp

MICHAUD Alexis and HÉ Xuéguāng 和学光 (2007). Reassociated tones and coalescent syllables in Naxi (Tibeto-Burman). Journal of the International Phonetic Association, 37(3), pp. 237-255.

MICHAUD Alexis and VAISSIÈRE Jacqueline (2008). Perceptual transcription and acoustic data: the example of /i/ in Yongning $\mathrm{Na}$ (Tibeto-Burman). Chinese Journal of Phonetics (中国语音学报), 2 (page numbers not communicated yet).

PINSON Thomas (1998). Naxi-Chinese-English Glossary, with English and Chinese Indexes. Dallas : The Summer Institute of Linguistics.

PULLUM Geoffrey and LADUSAW William (1986). Phonetic Symbol Guide. Chicago \& London: The University of Chicago Press.

SŪN Hóngkāi 孙宏开 (2001). Lùn Zàng-Mián yǔzú zhōng de Qiāng yǔzhī yǔyán 论藏缅语族中的㒸语支语言 [On the Qiangic branch of the Tibet-Burman language family]. Language and Linguistics, 2(1), pp. 157-181.

SUN Jackson T.S. (2003). Phonological profile of Zhongu: A new Tibetan dialect of Northern Sichuan. Language and Linguistics, 4(4), pp. 769-836.

YÁNG Fúquán 杨福泉 (2006). Nàmùȳ̄ yǔ Nà zhī zúqún guānxi kăolüè 纳 木依与纳之族群关系考略 [The ethnic relationship between the Namuyi and Na]. Mínzú yánjiū 民族研究, 3, pp. 52-59.

YÁNG Zhènhóng 杨振洪 (2006). Mósuōhuà Gàikuàng 摩梭话概况 [A sketch of the Mosuo language]. In : LATAMI Dashi (2006). Pp. 2864.

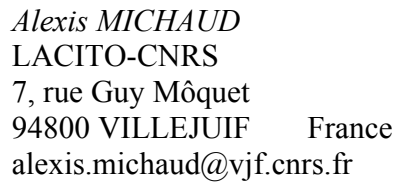

